\title{
Circulation, eddies, oxygen, and nutrient changes in the eastern tropical South Pacific Ocean
}

\author{
R. Czeschel $^{1}$, L. Stramma ${ }^{1}$, R. A. Weller ${ }^{2}$, and T. Fischer ${ }^{1}$ \\ ${ }^{1}$ GEOMAR Helmholtz Centre for Ocean Research Kiel, Düsternbrooker Weg 20, 24105 Kiel, Germany \\ ${ }^{2}$ Woods Hole Oceanographic Institution (WHOI), 266 Woods Hole Rd, Woods Hole, MA 02543, USA \\ Correspondence to: R. Czeschel (rczeschel@geomar.de)
}

Received: 1 September 2014 - Published in Ocean Sci. Discuss.: 23 September 2014

Revised: 26 March 2015 - Accepted: 1 June 2015 - Published: 22 June 2015

\begin{abstract}
A large subsurface oxygen deficiency zone is located in the eastern tropical South Pacific Ocean (ETSP). The large-scale circulation in the eastern equatorial Pacific and off the coast of Peru in November/December 2012 shows the influence of the equatorial current system, the eastern boundary currents, and the northern reaches of the subtropical gyre. In November 2012 the equatorial undercurrent (EUC) is centered at $250 \mathrm{~m}$ depth, deeper than in earlier observations. In December 2012, the equatorial water is transported southeastward near the shelf in the Peru-Chile undercurrent (PCUC) with a mean transport of $1.4 \mathrm{~Sv}$. In the oxygen minimum zone (OMZ), the flow is overlaid with strong eddy activity on the poleward side of the OMZ. Floats with parking depth at $400 \mathrm{~m}$ show fast westward flow in the mid-depth equatorial channel and sluggish flow in the OMZ. Floats with oxygen sensors clearly show the passage of eddies with oxygen anomalies. The long-term float observations in the upper ocean lead to a net community production estimate at about $18^{\circ} \mathrm{S}$ of up to $16.7 \mathrm{mmol} \mathrm{C} \mathrm{m}^{-3} \mathrm{yr}^{-1}$ extrapolated to an annual rate and $7.7 \mathrm{mmol} \mathrm{C} \mathrm{m}^{-3} \mathrm{yr}^{-1}$ for the time period below the mixed layer. Oxygen differences between repeated ship sections are influenced by the Interdecadal Pacific Oscillation (IPO), by the phase of El Niño, by seasonal changes, and by eddies, and hence have to be interpreted with care. At and south of the Equator the decrease in oxygen in the upper ocean since 1976 is related to an increase in nitrate, phosphate, and in part silicate.
\end{abstract}

\section{Introduction}

In all tropical oceans subsurface low oxygen layers exist at about $200 \mathrm{~m}$ to $700 \mathrm{~m}$ depths. In most of these oxygen minimum zones (OMZs) a decrease of oxygen was observed during the past decades, in a few areas oxygen increased (e.g., Keeling et al., 2010; Stramma et al., 2010a). Should observed decreases in oxygen continue this could lead to habitat compression, shifts in animal distribution, and loss of biodiversity with an impact on fisheries and economics. To understand the ongoing changes in OMZs, it is necessary to understand the circulation and its changes in the open ocean. A strong OMZ is located in the eastern tropical South Pacific Ocean (ETSP); however, the information on subsurface circulation changes and possible drivers for the oxygen changes is sparse.

The circulation in the ETSP is still not well described. For the upper ocean some circulation schemes have been developed (e.g., Kessler, 2006; Ayon et al., 2008; Grasse et al., 2012); however, information on the mid-depth circulation below $100 \mathrm{~m}$ depth is sparse due to the limited number of in situ observations.

The flow field in the eastern South Pacific is dominated by the Peru-Chile current system (PCCS), also called the Humboldt current system (HCS) (Chavez et al., 2008). In the equatorial Pacific, a complicated set of zonal currents exists (Fig. 1) which at $95^{\circ} \mathrm{W}$ in October-November 2003 had speeds of up to $0.9 \mathrm{~m} \mathrm{~s}^{-1}$ for the eastward flowing equatorial undercurrent (EUC) and are described as major supply paths of oxygen to the OMZs (e.g., Lukas, 1986; Collins et al., 2013; Stramma et al., 2010b). In the eastern Pacific, the equatorial currents weaken in part because of the presence of the Galapagos islands at the Equator (Karnauskas et 
al., 2010). The most important and best investigated equatorial currents include the westward flowing south equatorial current (SEC), with a northern band north of the Equator (SEC-N) and southern bands south of the Equator (SEC-S), the eastward flowing north and south equatorial countercurrents (NECC, SECC) at and below the surface, and the EUC as well as the northern and southern subsurface countercurrents (NSCC, SSCC) below about $50 \mathrm{~m}$ depth. The NSCC and SSCC start around $3^{\circ}$ from the Equator in the western Pacific, then gradually diverge and shoal to the east, with cores around $6^{\circ}$ from the Equator and $150 \mathrm{~m}$ below the surface by $110^{\circ} \mathrm{W}$ (Rowe et al., 2000). Another eastward current, the secondary SSCC (sSSCC) is found poleward of the SSCC and extends to greater densities (Rowe et al., 2000). Firing et al. (1998) described a westward south equatorial intermediate current (SEIC) and a north equatorial intermediate current (NEIC) centered around $500 \mathrm{~m}$ and $3^{\circ}$ from the Equator. A westward equatorial intermediate current (EIC) is often found below the EUC in the western Pacific (Firing et al., 1998). Even deeper, denser, and weaker eastward current extremes (north and south intermediate countercurrents - SICC, NICC) are found at about $2^{\circ}$ from the Equator from 500 to $1500 \mathrm{~m}$ (Firing et al., 1998).

The regions of equatorial upwelling and coastal upwelling are connected by the subsurface Peru-Chile undercurrent (PCUC) and the surface Peru-Chile countercurrent, where both are in part fed by the EUC. The subtropical gyre of the South Pacific Ocean contributes to several current bands of the SEC. Near the shelf it contributes to the Peru coastal current and the Peru oceanic current which flow equatorward in near-surface layers close to the coast and further than $\sim 150 \mathrm{~km}$ from the coast, respectively, and to a deep equatorward current, referred to as the Chile-Peru deep coastal current, flowing below the PCUC (Chaigneau et al., 2013).

From a large-scale hydrographic survey in February 2009, Czeschel et al. (2011) described the large-scale mid-depth circulation off the coast of Peru for the region of the OMZ at $400 \mathrm{~m}$ depth, including a comparison to model results and a discussion on the spreading paths of floats. As the mean currents are weak, eddy variability dominates the flow and the supply of oxygen to and the loss of oxygen from the OMZ (Czeschel et al., 2011).

During the last 2 decades eddies have been recognized to play an important role in the vertical and horizontal transport of momentum, heat, mass and the chemical constituents of seawater, such as oxygen and nutrients (e.g., Klein and Lapeyre, 2009), which might be especially important in regions with low oxygen layers. At least three types of eddies have been identified: cyclonic, anticyclonic, and mode water eddies (e.g., McGillicuddy Jr. et al., 2007) as well as a transition from cyclonic eddies to "cyclonic thinnies" to exist throughout the world ocean (McGillicuddy Jr., 2015). Cyclones dome both the seasonal and main pycnoclines, whereas anticyclones depress both density interfaces (McGillicuddy Jr. et al., 2007). Mode water eddies are

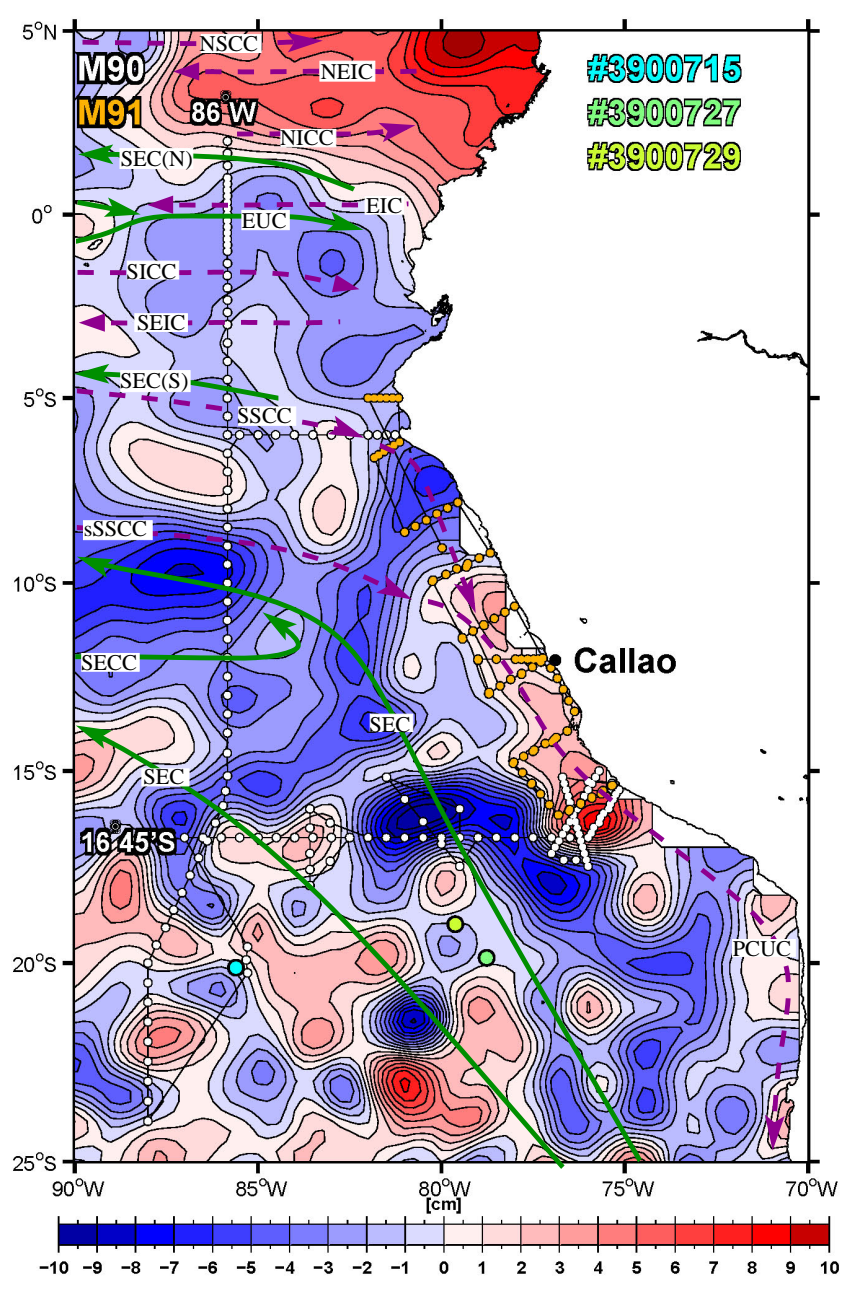

Figure 1. Aviso sea level height anomaly (in $\mathrm{cm}$ ) for 21 November 2012, cyclonic features are shown in blue, anticyclonic ones in red. The cruise track (black line) and conductivity-temperaturedepth (CTD) stations of R/V Meteor cruise M90 in November 2012 (white dots) and of cruise M91 in December 2012 (yellow dots) are included. The deployment locations of the three floats used here are marked by filled greenish circles with the related world meteorological organization (WMO) number shown in the right upper corner. Near-surface currents are shown as solid green lines, subsurface currents as dashed magenta lines. Abbreviations for current bands are listed in the text.

most commonly referred as intrathermocline eddies (ITEs) (Hormazabal et al., 2013). Mode water eddies (ITEs) consist of a bolus of fluid that depresses the main thermocline and raises the seasonal thermocline (McGillicuddy, 2015). In the South Pacific they are represented by subsurface lenses $(\sim 100 \mathrm{~km}$ diameter; $500 \mathrm{~m}$ thickness) of nearly homogeneous salinity (> 34.5) and oxygen-deficient $\left(<1.0 \mathrm{~mL} \mathrm{~L}^{-1}\right)$ waters, properties linked to the equatorial subsurface water mass (ESSW) transported poleward by the PCUC (Hormazabal et al., 2013). Data from a cruise in November 2012 have been used to describe the nutrient distribution in eddies off 
the shelf of southern Peru with enhanced oxygen values in the center of cyclonic eddies and lower oxygen values in the center of anticyclonic eddies (Stramma et al., 2013). Close to the Equator hardly any eddies are seen in sea surface height anomaly satellite data, in part due to technical difficulties, while off the southern coast of Peru many cyclonic and anticyclonic eddies are observable (Chelton et al., 2011). The eddy frequency off the coast of Peru at 15 to $18^{\circ} \mathrm{S}$ reaches up to $50 \%$ (Chaigneau et al., 2008). At the Stratus mooring $\left(\sim 20^{\circ} \mathrm{S}, 85^{\circ} \mathrm{W}\right)$ about $1000 \mathrm{~km}$ off the South American continent, a strong mode water eddy was observed that formed 11 months earlier off the Chilean shelf (Stramma et al., 2014).

Profiling floats are ideal tools for continuous sampling of the ocean instead of short-time measurements from ships. Besides CTD profiles, additional parameters can be measured on floats, including oxygen to extend oxygen time series. Floats with oxygen sensors were used in the past to investigate the net production of oxygen in the subtropical ocean (Riser and Johnson, 2008), to describe the oxygen distribution on a float drifting from Chile to Peru (Ulloa et al., 2012), and to collect oxygen time series to investigate oxygen trends (Czeschel et al., 2012).

Long-term oxygen trends were observed in the equatorial Pacific (e.g., Stramma et al., 2010b), which are overlaid by climate-forced variations like El Niño, and the Pacific decadal oscillation (Deutsch et al., 2011). Based on model results, the decadal and bi-decadal climate variability in the tropical Pacific is controlled by the off-equatorial South Pacific Ocean (Tatebe et al., 2013). Hence, a comparison of recent measurements with earlier surveys might help to find out whether the model derived climate connections are visible in observations.

Here we will use the hydrographic data from an openocean cruise leg in November 2012 and a near-shelf leg in December 2012 to investigate the large-scale circulation in subsurface layers of the ETSP and its impact on the oxygen distribution and oxygen changes. These results will be compared to sections from earlier cruises and to float data to better define the large-scale circulation and to describe changes and trends in the circulation and parameter distributions. In addition, float data will be used to describe the passage of eddies and to provide a net community production estimate for the eastern South Pacific. The aim of this investigation is to better understand the flow field and its variability on different timescales and changes caused by eddies. This will help to better understand the existing shape of the OMZ in the ETSP and its changes with time.

\section{The data set}

Cruises M90 and M91 on the German research vessel R/V Meteor took place in November and December 2012 to investigate the factors controlling the intensity and areal extent of the OMZ of the eastern tropical Pacific Ocean. The cruise M90 started in Cristóbal, Panama, on 29 October and ended on 28 November 2012 in Callao, Peru. Cruise M91 started in Callao, Peru, on 1 December 2012. Several sections perpendicular to the shelf and parallel to the shelf were carried out from north to south between 5 and $16^{\circ} \mathrm{S}$ (Fig. 1). The cruise M91 ended again in Callao on 26 December 2012.

On cruise M90 a former World Ocean Circulation Experiment section along $85^{\circ} 50^{\prime} \mathrm{W}-88^{\circ} \mathrm{W}$ (WOCE Sect. P19) was reoccupied from $2^{\circ} \mathrm{N}, 85^{\circ} 50^{\prime} \mathrm{W}$ on 1 November to $24^{\circ} \mathrm{S}$, $88^{\circ} \mathrm{W}$ on 13 November; this section had been sampled in late March 1993 on R/V Knorr (Tsuchiya and Talley, 1998) with the northernmost station used here occupied during the R/V Knorr cruise on 1 April 1993. This section, called the $86^{\circ} \mathrm{W}$ section in the following, is located at $85^{\circ} 50^{\prime} \mathrm{W}$ between $2^{\circ} \mathrm{N}$ and $15^{\circ} 07^{\prime} \mathrm{S}$ and shifts to $88^{\circ} \mathrm{W}$ between $15^{\circ} 07^{\prime} \mathrm{S}$ and $20^{\circ} \mathrm{S}$. The $86^{\circ} \mathrm{W}$ section had been sampled already on a cruise with R/V Meteor (Meteor cruise M77/4 from Callao 27 January to Panama 18 February 2009) between $14^{\circ} \mathrm{S}$ on 1 February 2009 and $2^{\circ} \mathrm{N}$ on 16 February 2009. A section along $6^{\circ} \mathrm{S}$ east of $85^{\circ} 50^{\prime} \mathrm{W}$ sampled in February 2009 was reoccupied. Starting on 15 November 2012 another former WOCE section along $16^{\circ} 45^{\prime} \mathrm{S}$ sampled in April 1994 was reoccupied by following an eastward cruise track from $87^{\circ} \mathrm{W}$ to the coast of Peru (Fig. 1). The CTD station spacing was $0.5^{\circ}$ on the openocean sections, but was reduced in the equatorial channel as well as for the near-shelf stations and the sections across the eddies.

On the basis of satellite sea level height anomaly images forwarded to the ship, several eddies were identified in the area in November 2012. A detailed survey of two major anticyclonic eddies and one cyclonic eddy along the $16^{\circ} 45^{\prime} \mathrm{S}$ section including acoustic Doppler current profiling (ADCP), measurements of CTD, and of major biogeochemical parameters $\left(\mathrm{O}_{2}\right.$, nutrients, chlorophyll, and turbidity) along several additional subsections across the eddies had been performed in an earlier study (Stramma et al., 2013).

Two ADCP systems recorded the ocean velocities in November/December 2012: a hull mounted RDI OceanSurveyor $75 \mathrm{kHz}$ ADCP provided the velocity distribution to about $700 \mathrm{~m}$ depth, while a $38 \mathrm{kHz}$ ADCP mounted in the sea well provided velocity profiles down to about $1200 \mathrm{~m}$ depth. As this investigation is on the upper ocean the data shown in this study are from the $75 \mathrm{kHz}$ ADCP for the November 2012 cruise, while for the December 2012 cruise the 75 and $38 \mathrm{kHz}$ ADCP values were combined with a linear weight transition of $5: 1$ for $78: 38 \mathrm{kHz}$ at the surface and $1: 5$ at $800 \mathrm{~m}$ depths to reach deeper transport estimates at the shelf. For the R/V Meteor cruise in February 2009 only the $75 \mathrm{kHz}$ ADCP was available. The bin size of the 75 and $38 \mathrm{kHz}$-ADCP measurements was $8 \mathrm{~m}$ with the uppermost usable velocity depth at $21 \mathrm{~m}$. The shipboard ADCP on the R/V Knorr 1993 cruise reached a maximum depth of $493 \mathrm{~m}$. Lowered ADCP data were collected north of $5^{\circ} \mathrm{S}$ in March 1993 and are used here 
to extend the vertical range of shipboard ADCP data of the R/V Knorr 1993 cruise.

A Seabird CTD system with a General Oceanics rosette with $2410 \mathrm{~L}$ water bottles was used for water profiling and discrete water sampling on both cruises. Except for some deep profiles, the nominal sampling depth was $1200 \mathrm{~m}$ on the $86^{\circ} \mathrm{W}$ section, $1500 \mathrm{~m}$ on the $16^{\circ} 45^{\prime} \mathrm{S}$ section and $2000 \mathrm{~m}$ for the M91 cruise in December 2012 when off the shelf. The CTD system was used with double sensors for temperature, conductivity (salinity), and oxygen. The CTD-oxygen sensors were calibrated with oxygen measurements obtained from discrete samples from the rosette applying the classical Winkler titration method, using a non-electronic titration stand (Winkler, 1888; Hansen, 1999). The precision of the oxygen titration determined during cruise M90 in November 2012 was $\pm 0.45 \mu \mathrm{mol} \mathrm{L}^{-1}$. The uncertainty of the CTDoxygen sensor calibration was determined as a root mean square (rms) of $\pm 0.68 \mu \mathrm{mol} \mathrm{kg}{ }^{-1}$. However, with the classical titration method we were not able to determine oxygen concentrations below about $2 \mu \mathrm{mol} \mathrm{kg}^{-1}$ and hence oxygen concentrations below about $2 \mu \mathrm{mol} \mathrm{kg}{ }^{-1}$ could not be measured with the CTD-oxygen sensors as well.

The oxygen background fields were taken from the Commonwealth scientific and industrial research organization (CSIRO) Atlas of Regional Seas (CARS) 2009 digital climatology (Ridgway et al., 2002), for the November values above $400 \mathrm{~m}$ depth and the annual mean below $400 \mathrm{~m}$ depth.

Aviso satellite derived altimeter sea surface height anomaly data (SSHA) were used to define the general background distribution of the circulation and eddies. The SSHA data used in this study are delayed time products and combine available data of all satellites. The data are resampled on a regular $0.25^{\circ} \times 0.25^{\circ}$ grid and are calculated with respect to a 7-year mean (http://www.aviso.oceanobs.com).

In the framework of the VOCALS project (Mechoso et al., 2014) 10 floats with Seabird SBE 43 oxygen sensors integrated into a SBE41CP CTD were deployed in October 2008 at about $20^{\circ} \mathrm{S}$ between 75 and $85^{\circ} \mathrm{W}$ with a parking depth of $1000 \mathrm{~m}$. Six of the floats failed within the first months; however, four floats provided good oxygen time series until February 2014 with an initial cycling interval of 3 days in the upper 600 to $800 \mathrm{~m}$ depth. After about $11 \mathrm{months}$ the cycling interval was increased to 10 days. Details of the three floats used here are given in Table 1.

Ten profiling floats with Aanderaa oxygen sensors from the German research initiative SFB-754 were deployed in February 2009 along the $85^{\circ} 50^{\prime} \mathrm{W}$ section, in pairs at 10, $8,6,4$, and $2^{\circ} \mathrm{S}$; one of each pair had a parking depth of $400 \mathrm{dbar}$ and the other $1000 \mathrm{dbar}$. An additional eight floats with Aanderaa oxygen sensors were deployed in April 2011 along $20^{\circ} \mathrm{S}$ at $75.58,76.49,77.01$, and $85.68^{\circ} \mathrm{W}$. These floats were again deployed in pairs with drifting depths at 400 and $1000 \mathrm{dbar}$, and cycling intervals of 10 days. Satellite data were used during the 2011 cruise to find eddy features and deploy the floats in eddies. The shallow parking depth of our floats is a particular difference compared to most floats of other groups, which have parking depths of about $1000 \mathrm{~m}$ and $1500 \mathrm{~m}$ and can be used to describe the flow field in these depth layers (e.g., Cravatte et al., 2012). The floats drifting at 400 dbar were particularly aimed to analyze their spreading behavior near the core of the OMZ of the eastern Pacific.

\section{Results and discussion}

\subsection{The circulation of the oxygen deficiency zone in the eastern tropical South Pacific Ocean}

The distribution of current bands at $86^{\circ} \mathrm{W}$ shows the currents responsible for oxygen supply by eastward flow into the OMZ and westward transport of oxygen-poor water by westward current bands. The ADCP velocity distribution along about $86^{\circ} \mathrm{W}$ (Fig. 2a) shows the typical equatorial current bands like the EUC, SICC, SEIC, and the SSCC. The eastward flow in the equatorial channel as well as the two SSCC current bands are connected to higher oxygen values compared to the westward SEC current bands with low oxygen at subsurface layers. However, there are differences compared to the distribution described in literature. The strong subsurface eastward flow at about $12.5^{\circ} \mathrm{S}$ is located in the region of possible SECC flow; however, as this current has a subsurface core, it might not be the SECC but could be caused by the cyclonic feature located in this region in November 2012 (Fig. 1). In February 2009 (Czeschel et al., 2011; their Fig. 2) the current was located at $12^{\circ} \mathrm{S}$, reached to the sea surface and was identified as the SECC. South of $15^{\circ} \mathrm{S}$, the velocities are predominantly westward, showing the northern part of the South Pacific subtropical gyre. Overlain on this westward flow are the signatures of two shallow cyclonic features at about 23.5 and $18^{\circ} \mathrm{S}$ and a deeper reaching anticyclonic feature at about $22^{\circ} \mathrm{S}$ (Fig. 2), which are also visible in the sea level height anomaly on 10 to 13 November 2012 when the section south of $15^{\circ} \mathrm{S}$ was measured and still visible on 21 November (Fig. 1). The isopycnals show a dome shape and higher oxygen in the core of the cyclonic features and a bowl shape and lower oxygen for the anticyclonic feature centered at the location where the zonal velocity component reverses (Fig. 2).

In the eastern Pacific typically the SSCC core is located in the potential density anomaly range $26.2-26.5 \mathrm{~kg} \mathrm{~m}^{-3}$ around $6^{\circ} \mathrm{S}$ (e.g., Stramma et al., 2010b; Czeschel et al., 2011) with a weak but consistent SSSCC poleward of the SSCC and extending to greater densities (Rowe et al., 2000). In November 2012, however, the sSSCC was stronger than the SSCC especially in the potential density anomaly range $26.2-26.5 \mathrm{~kg} \mathrm{~m}^{-3}$ while the SSCC was very weak (Fig. 2a). Both SSCC bands showed an unusually strong eastward component in the depth range 400 to $700 \mathrm{~m}$.

The Galapagos islands form a $135 \mathrm{~km}$ wide barrier to the EUC straddling the Equator at $91.66^{\circ} \mathrm{W}$. Here the 
Table 1. VOCALS floats with oxygen sensors used here. The autonomous profiling explorer (APEX) floats had cycle intervals of 3 days for the first 11 months, and then the cycling interval was increased to 10 days. The APEX floats stayed at the surface for about $13 \mathrm{~h}$ while the PROVOR float stayed at the surface for about $7 \mathrm{~h}$. According to the parking depths the floats are named here f330, f350, and $\mathrm{f} 400$. The deployment positions are shown in Fig. 1.

\begin{tabular}{lllll}
\hline WMO no. & Parking depth & Deployment date & Deployment position & No. of profiles \\
\hline 3900715 & $1000 \mathrm{~m}$ & 25 Oct 2008 & $20.11^{\circ} \mathrm{S}, 85.60^{\circ} \mathrm{W}$ & $276(26$ Oct 2008-8 Apr 2014) \\
3900727 & $1000 \mathrm{~m}$ & 16 Nov 2008 & $19.86^{\circ} \mathrm{S}, 78.77^{\circ} \mathrm{W}$ & $307(17$ Nov 2008-26 Feb 2015) \\
3900729 & $1000 \mathrm{~m}$ & 17 Nov 2008 & $19.00^{\circ} \mathrm{S}, 79.62^{\circ} \mathrm{W}$ & $300(18$ Nov 2008-21 Feb 2015) \\
\hline
\end{tabular}

EUC bifurcates into a shallower/southern core (EUCs) and a deeper/northern core (EUCd) (Karnauskas et al., 2010). Mooring observations at the Equator at 110,95 and $85^{\circ} \mathrm{W}$ showed a strong EUC signal with a core above $100 \mathrm{~m}$ depth in February 1982 at 110 and $95^{\circ} \mathrm{W}$ and at $150 \mathrm{~m}$ depth in November 1981 at $85^{\circ} \mathrm{W}$ (Karnauskas et al., 2010; Fig. 1). Our ADCP measurements in November 2012 showed the core of the EUCd even deeper at about $250 \mathrm{~m}$ depth, while the EUCs is missing at the Equator, but may be shifted southward to $3-4^{\circ} \mathrm{S}$ in the upper $100 \mathrm{~m}$ (Fig. 2a) as a flow that deflects southeastward toward the coast of Peru (Karnauskas et al., 2010). In March 1993 and in February 2009 (Czeschel et al., 2011) the eastward flow of the EUC at $85^{\circ} 50^{\prime} \mathrm{W}$ was observed almost completely in the upper $200 \mathrm{~m}$ between $2^{\circ} \mathrm{S}$ and $2^{\circ} \mathrm{N}$ with a transport of $16.3 \mathrm{~Sv}$ in March 1993 and in 4.9 Sv in February 2009. The observed EUC at $85^{\circ} 50^{\prime} \mathrm{W}$ in the $2^{\circ} \mathrm{S}$ to $2^{\circ} \mathrm{N}$ box in the upper $200 \mathrm{~m}$ is $7.2 \mathrm{~Sv}$ for November 2012; however, as described above, at that time part of the EUC transport was at deeper depth.

Based on observations at $95^{\circ} \mathrm{W}$, a strong EUC season was defined for March to July with a weak EUC for October to December (Karnauskas et al., 2010). Results from a climate model for $110^{\circ} \mathrm{W}$ (Cravatte et al., 2007) show an increase in the surface eastward EUC current during boreal spring while during other seasons, the EUC is deeper. Hence, the stronger EUC at the end of March 1993 compared to mid-February 2009 is in agreement with the Karnauskas et al. (2010) results, while the enhanced deep EUC in November 2012 compared to mid-February 2009 is in agreement with the Cravatte et al. (2007) results and shows the influence of the seasonal signal on the EUC.

The EUCd is connected in November 2012 to the SICC, with the isopycnal $26.65 \mathrm{~kg} \mathrm{~m}^{-3}$ as boundary between these two current bands. With the strong EUCd the EIC which was well visible in February 2009 (Czeschel et al., 2011) is not visible in November 2012, but only a reduced eastward flow component is seen at about $400 \mathrm{~m}$ depth north of the SICC near the Equator.

The circulation at different depths off the coast of Peru in November/December 2012 obtained from ADCP measurements, color coded with the oxygen of adjacent CTD-oxygen profiles, shows the transport paths of oxygen-rich water towards the OMZs in the equatorial region (Fig. 3) below the
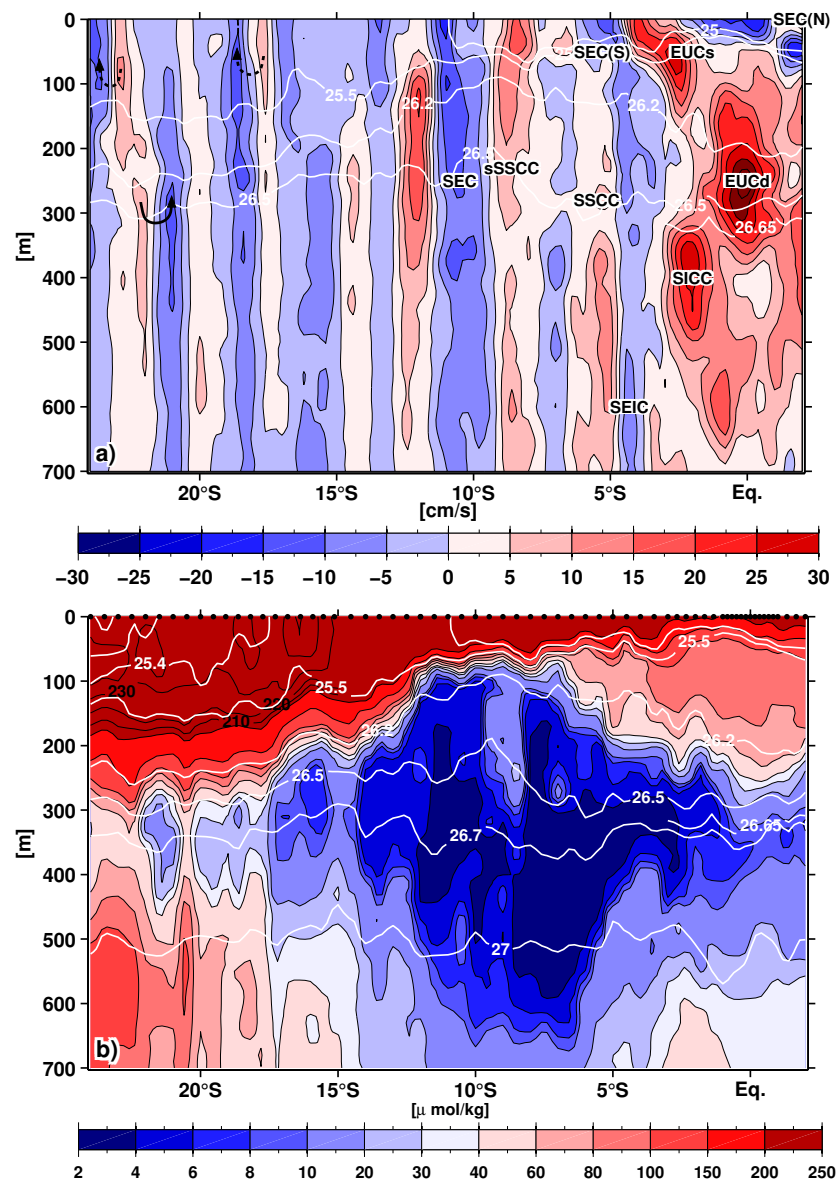

Figure 2. (a) Zonal velocity distribution in $\mathrm{cm} \mathrm{s}^{-1}$ (positive eastward) along about $86^{\circ} \mathrm{W}$ between $2^{\circ} \mathrm{N}$ and $24^{\circ} \mathrm{S}$ from the shipboard ADCP velocity data measured 1 to 13 November 2012. See text for indicated current bands. Some selected isopycnals are included as white lines. Cyclonic features at the southern part of the section are marked as dashed black arrows, an anticyclonic feature as solid black arrow. (b) Oxygen distribution in $\mu \mathrm{mol} \mathrm{kg}{ }^{-1}$ (contour interval $10 \mu \mathrm{mol} \mathrm{kg}^{-1}$ and the $235 \mu \mathrm{mol} \mathrm{kg}{ }^{-1}$ contour) with isopycnals as in (a) plus some additional isopycnals. CTD station locations are marked by black dots at the surface.

surface layer. At $50 \mathrm{~m}$ depth (Fig. 3a), the lowest CARSclimatological oxygen is located at the equatorial channel and near the South American continent due to equatorial 
and coastal upwelling. The in situ observations in November 2012 show deviations from the climatological mean, e.g., an eastward flowing current at about $3-4^{\circ} \mathrm{S}$ and the upper reaches of the sSSCC at about $9^{\circ} \mathrm{S}$ supply oxygen-rich water to the eastern Pacific. Near the shelf oxygen-poor water is transported alongshore at $50 \mathrm{~m}$ depth with northwestward as well as southeastward flow components. Near $16^{\circ} \mathrm{S}$ high oxygen values at $50 \mathrm{~m}$ depth are related to water from the open-ocean circulating around the anticyclonic eddy located near the shelf break at the end of 2012 (Stramma et al., 2013), while the low oxygen at $50 \mathrm{~m}$ marks the core of the mode water eddy.

In the upper OMZ at $200 \mathrm{~m}$ depth (Fig. 3b) the low oxygen core is centered at about $12^{\circ} \mathrm{S}$ and reaches from the southern Peruvian coast into the open ocean. The in situ observations agree with the low CARS-oxygen distribution in the center of the OMZ. The highest oxygen concentration in $200 \mathrm{~m}$ depth is observed in the southwest in the northern reaches of the South Pacific subtropical gyre, connected to a broad westward flow component. Near the Equator, eastward supply of oxygen by eastward flow also agrees with the climatological oxygen distribution. At the $6^{\circ} \mathrm{S}$ section the northward flow component carries oxygen-poor water to the north. At the $16^{\circ} 45^{\prime} \mathrm{S}$ section the westward flow with low oxygen water reaches further west than the climatological mean. The anticyclonic eddy centered south of $16^{\circ} \mathrm{S}$ is slightly lower in oxygen than the CARS climatology and exhibits the reduced oxygen distribution in the mode water eddy at $200 \mathrm{~m}$ depth.

The core of the OMZ is located at about $375 \mathrm{~m}$ depth. The ADCP velocity and in situ oxygen observations show even lower oxygen values than expected from the climatological mean (Fig. 3c) with less than $10 \mu \mathrm{mol} \mathrm{kg}^{-1}$ in almost the entire measurement region including the equatorial channel; the only exception is the subtropical gyre in the southwest. Even the eastward flowing SICC north of $4^{\circ} \mathrm{S}$ transports low oxygen compared to the CARS climatology eastward. At $16^{\circ} 45^{\prime} \mathrm{S}$ near the shelf, the low oxygen and the anticyclonic circulation is related to the strong anticyclonic mode water eddy.

The lower part of the OMZ at $600 \mathrm{~m}$ depth (Fig. 3d) shows the low oxygen layer restricted in the eastern South Pacific to the region from 5 to $13^{\circ} \mathrm{S}$. Near the Equator there is again eastward oxygen supply by the lower part of NICC and SICC. In most locations the November/December 2012 flow field agrees with the climatology. The westward SEC at $10-12^{\circ} \mathrm{S}$ is located a bit more south transporting low oxygen water westward and again the westward flow at $16^{\circ} 45^{\prime} \mathrm{S}$ with low oxygen water reaches further south than in the climatological mean.

The smoothed velocity distribution on the sections off the Peruvian coast in December 2012 (see Fig. 1) shows the southeastward flowing PCUC with variable structure and strength (Fig. 4). The southeastward transports for the depth layer 25 to $500 \mathrm{~m}$ up to $200 \mathrm{~km}$ off the coast are $-1.0 \mathrm{~Sv}$ at $5^{\circ} \mathrm{S},-2.3 \mathrm{~Sv}$ at $7^{\circ} \mathrm{S},-1.0 \mathrm{~Sv}$ at $9^{\circ} \mathrm{S},-1.2 \mathrm{~Sv}$ at $10^{\circ} \mathrm{S}$,
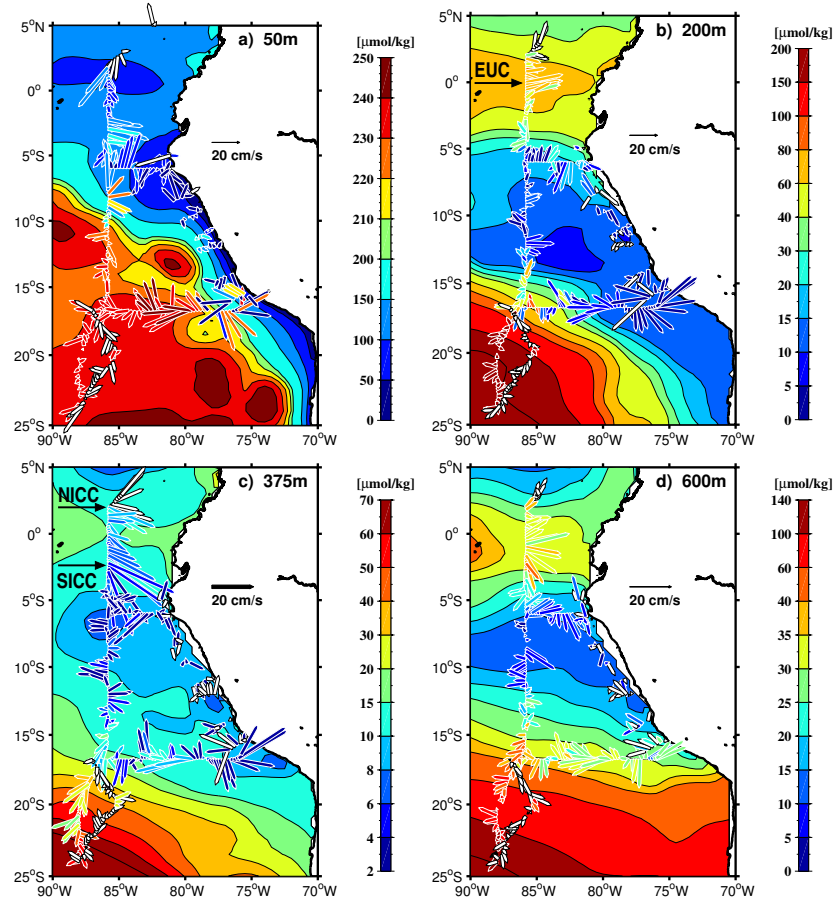

Figure 3. Horizontal distribution of ADCP velocity vectors at (a) $50 \mathrm{~m}$, (b) $200 \mathrm{~m}$, (c) $375 \mathrm{~m}$, and (d) $600 \mathrm{~m}$ depth recorded in November and December 2012 with current vectors colored with oxygen (in $\mu \mathrm{mol} \mathrm{kg}-1$ ) of the accompanying CTD-oxygen measurement at this depth. In case of no accompanying CTD-oxygen measurement the current vectors are white. The oxygen distribution of the background field is from the CARS 2009 climatology (Ridgway et al., 2002) for November at 50, 200, and $375 \mathrm{~m}$ and the annual mean at $600 \mathrm{~m}$ depth. Please note the different color scales adjusted to fit the corresponding depth layer oxygen range. The locations of the equatorial undercurrent (EUC) and the Northern and Southern Intermediate Current (NICC, SICC) are marked.

$-2.5 \mathrm{~Sv}$ at $11^{\circ} \mathrm{S}$ east of $79^{\circ} \mathrm{W},-0.5 \mathrm{~Sv}$ at $13^{\circ} \mathrm{S},-2.4 \mathrm{~Sv}$ at $14^{\circ} \mathrm{S}$, and $-0.2 \mathrm{~Sv}$ at $16^{\circ} \mathrm{S}$ near the shelf. At $5^{\circ} \mathrm{S}$ the core of the PCUC is located west of the shelf break probably due to the contribution of the southern band of the EUC (Chaigneau et al., 2013; their Fig. 1). At 7, 9, and $10^{\circ} \mathrm{S}$ the PCUC is attached to the shelf. At $11^{\circ} \mathrm{S}$ the maximum transport of $-2.5 \mathrm{~Sv}$ is reached for the current at the shelf east of $79^{\circ} \mathrm{W}$ with water from the SSCC. The second current core west of $79^{\circ} \mathrm{W}$ might be water from the sSSCC moving southward. At 13 and $14^{\circ} \mathrm{S}$ the PCUC near the shelf weakens due to a deep equatorward current flowing below the PCUC and referred to as Chile-Peru deep coastal current by Chaigneau et al. (2013). The northward transport of the Chile-Peru deep coastal current east of $77.3^{\circ} \mathrm{W}$ above $800 \mathrm{~m}$ depth is $2.6 \mathrm{~Sv}$ in good agreement with glider measurements in April-May 2010 at $14^{\circ} \mathrm{S}$ of $2.5 \mathrm{~Sv}$ (Pietri et al., 2014). These glider measurements of $\sim-2.5 \mathrm{~Sv}$ for the PCUC agree again well with our transport of $-2.4 \mathrm{~Sv}$ at $14^{\circ} \mathrm{S}$. 

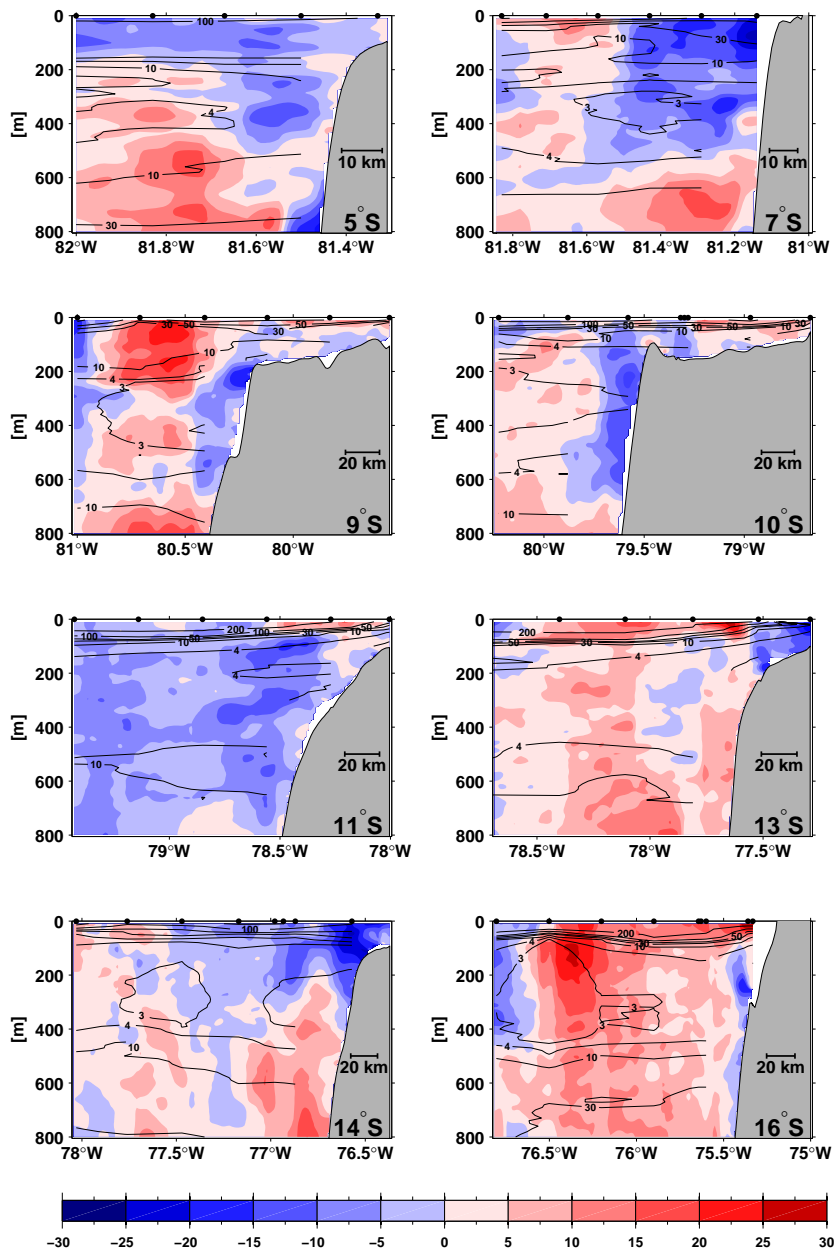

Figure 4. Smoothed cross section velocity component parallel to the coast in $\mathrm{cm} \mathrm{s}^{-1}$ (positive northwestward) for sections perpendicular to the coast near the Peruvian shelf (see Fig. 1) at about 5, $7,9,10,11,13,14$, and $16^{\circ} \mathrm{S}$ in December 2012. Included are selected smoothed oxygen contours in $\mu \mathrm{mol} \mathrm{kg}{ }^{-1}$ as black lines. CTD station locations are marked by black dots at the surface.

At $16^{\circ} \mathrm{S}$ the PCUC is weak with only $0.2 \mathrm{~Sv}$ near the shelf, as at that time a strong anticyclonic mode water eddy was located south of this section at the shelf (Stramma et al., 2013). The velocity components at different depths (Fig. 3) show that the $16^{\circ} \mathrm{S}$ section contains a strong northwestward flow component of this eddy and the oxygen distribution shows the low oxygen core at the flow reversal at the $16^{\circ} \mathrm{S}$ section. The region near the shelf north of $15^{\circ} \mathrm{S}$ has an eddy frequency of about 20 to $30 \%$ while south of $15^{\circ} \mathrm{S}$ it has an eddy frequency of up to $50 \%$ (Chaigneau et al., 2008); hence, the PCUC is disturbed by eddies mainly in the southern region of Peru.

The mean alongshore southeastward transport of the eight sections between 5 and $16^{\circ} \mathrm{S}$ is $1.4 \mathrm{~Sv}$ and agrees with the $1.6 \pm 0.4 \mathrm{~Sv}$ from long-term measurements between 7 and $13^{\circ} \mathrm{S}$ (Chaigneau et al., 2013). Between 13 and $9^{\circ} \mathrm{S}$ an equa- torward flow in the upper $100 \mathrm{~m}$ is seen which could be part of the Peru coastal current, seen in the same geographical region at $25 \mathrm{~m}$ depth in the mean flow field (Chaigneau et al., 2013; their Fig. 3). The oxygen distribution at $5^{\circ} \mathrm{S}$ shows slightly higher values at 200 to $400 \mathrm{~m}$ depth in the PCUC compared to the northward flow west of about $71.7^{\circ} \mathrm{W}$ (Fig. 4). This is related to the enhanced oxygen in the equatorial region feeding the PCUC, which is also visible in the climatological oxygen distribution at 200 and $375 \mathrm{~m}$ depth (Fig. 3b, c). In the upper $200 \mathrm{~m}$ near the shelf at $7^{\circ} \mathrm{S}$ the oxygen is higher than offshore (Fig. 4) and could be a contribution from equatorial southward flow along the shelf called Ecuador-Peru coastal current by Chaigneau et al. (2013). Although variable the oxygen distribution between 9 and $14^{\circ} \mathrm{S}$ shows low oxygen in the PCUC region. In the near-surface layer near the shelf upwelling is indicated in the oxygen distribution between 9 and $13^{\circ} \mathrm{S}$.

\subsection{Float measurements}

The nine floats deployed with a parking depth at $400 \mathrm{dbar}$ provide information on the long-term spreading and variability at about $400 \mathrm{~m}$ depth. The floats provided data for time periods between 710 and 1780 days (Fig. 5). The floats deployed at 2, 4 and $6^{\circ} \mathrm{S}$ all moved rapidly westward within the equatorial current system. The fastest westward velocity with a mean northwest flow of $4.2 \mathrm{~cm} \mathrm{~s}^{-1}$ was that of the float deployed at $2^{\circ} \mathrm{S}$, which entered the EIC and moved rapidly westward, before it left the EIC at $115^{\circ} \mathrm{W}$ and moved northward. The floats deployed at 4 and $6^{\circ} \mathrm{S}$ moved westward within the SEIC north of $5^{\circ} \mathrm{S}$ and the float deployed at $4^{\circ} \mathrm{S}$ shifted into the eastward flowing SSCC at about $108^{\circ} \mathrm{W}$ and moved back to $93^{\circ} \mathrm{W}$ before shifting again into the SEIC. As can be seen from the mean oxygen distribution at $400 \mathrm{~m}$ depth the SEIC carries the tongue of low oxygen far westward. The floats deployed at 8 and $10^{\circ} \mathrm{S}$ were located in a stagnant flow region (Czeschel et al., 2011) and moved slowly with less than $1 \mathrm{~cm} \mathrm{~s}^{-1}$ in the mean to the south.

The floats with a parking depth at $400 \mathrm{dbar}$ deployed in April 2011 along $20^{\circ} \mathrm{S}$ are in the transition region between the OMZ and the well-oxygenated subtropical gyre. These floats are strongly influenced by eddies, which is reflected in the float paths (Fig. 5). Three of the floats moved slowly $\left(\sim 1 \mathrm{~cm} \mathrm{~s}^{-1}\right)$ westward with a slight southward component for the two floats east of $80^{\circ} \mathrm{W}$, while one float entered the Peru coastal current and was transported northwestward.

Profiling floats sometimes are trapped for some time in eddies. Floats equipped with oxygen sensors are able to register the water mass and oxygen changes of an eddy when trapped in an eddy. A float with an oxygen sensor (float 3900715) deployed on 26 October 2008 at $20.1^{\circ} \mathrm{S}, 85.6^{\circ} \mathrm{W}$ had a lifetime of only 1.5 years. This float stayed for more than half a year in a cyclonic eddy (Fig. 6). The float path shows two cyclonic loops (Fig. 6a) while trapped in the cyclonic eddy, which lead to an uprise of the low oxygen layer in the up- 


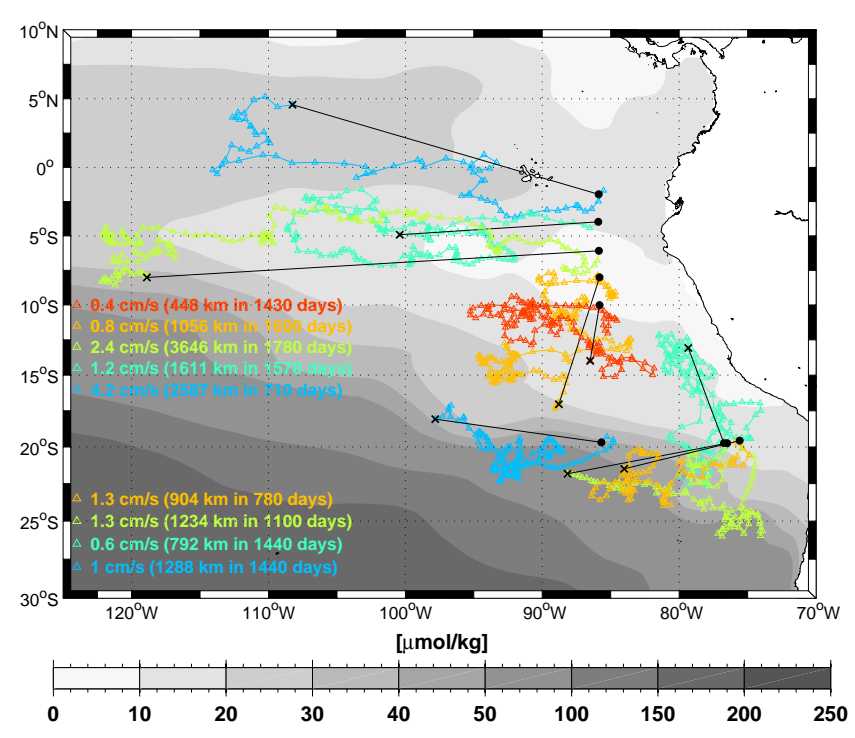

Figure 5. Floats drifting at 400 dbar deployed in February 2009 along $85^{\circ} 50^{\prime} \mathrm{W}$ and in April 2011 along $20^{\circ} \mathrm{S}$ (in color) with mean velocity information for the entire lifetime of the floats or until March 2015 for floats which are still active. The symbols show the surfacing location every 10 days, the black line marks the connection between the deployment position and the last position used. Grey background field is the annual mean CARS 2009 (Ridgway et al., 2002) climatological oxygen distribution in $\mu \mathrm{mol} \mathrm{kg}-1$ at $400 \mathrm{~m}$ depth.

per ocean (Fig. 6b). The strongest oxygen anomaly is located at about $300 \mathrm{~m}$ depth and the potential density anomaly, salinity, potential temperature, and oxygen time series were plotted at $300 \mathrm{~m}$ depth and show an increase in the potential density anomaly and the salinity, a potential temperature decrease as well an oxygen decrease at $300 \mathrm{~m}$ depth (Fig. 6d-g). The 450 to $250 \mathrm{~m}$ geopotential anomaly (Fig. 6c) shows a strong decrease from late March to September 2009. The SSHA anomaly was extracted from the daily-delayed time product at the float location and the SSHA shows very good agreement with the geopotential anomaly at the subsurface layer. The animation of the float location relative to the SSHA (Supplement movie F1) shows the cyclonic movement. At the beginning of the float mission the float crosses a regular anticyclonic eddy before it completes two full loops around the strong cyclonic eddy (Fig. 6a). The cyclonic eddy moves westward and the cyclonic loops during the westward shift are well visible in the Supplement movie. The flow path at the end of the cyclonic eddy influence looks like an anticyclonic movement; however, inspection of the satellite data showed that the float moved southward at the boundary of the cyclonic eddy before it entered an anticyclonic eddy in October 2009. This is visible in the low oxygen layer located at $350 \mathrm{~m}$ depth (Fig. 6b) as well as in the oxygen at $300 \mathrm{~m}$ depth (Fig. 6g).
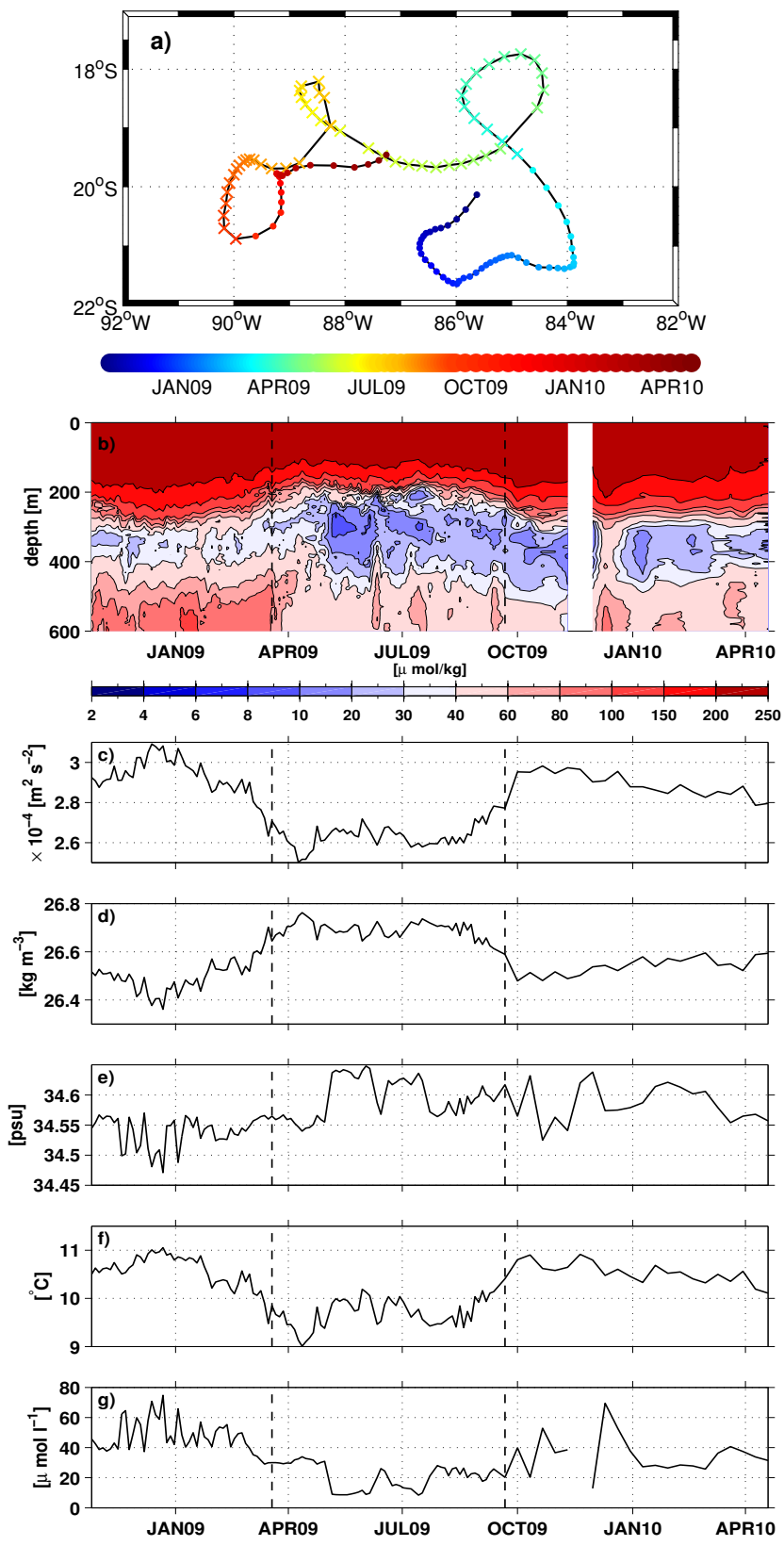

Figure 6. Measurements of float 3900715 in the tropical eastern South Pacific between 26 October 2008 and 19 April 2010 with (a) float path (color coded), (b) oxygen distribution versus time in the upper $600 \mathrm{~m}$, (c) geopotential anomaly (450 to $250 \mathrm{~m}$, black curve) and SSHA from daily delayed-time satellite data at the float location (red curve), (d) potential density anomaly in $300 \mathrm{~m}$ depth, (e) salinity in $300 \mathrm{~m}$, (f) potential temperature in $300 \mathrm{~m}$, and (g) oxygen in $300 \mathrm{~m}$. An erroneous oxygen profile in early November 2009 was removed. The float residence time of the float in the cyclonic eddy (19 March 2009 to 21 September 2009) is marked by Xs (a) and dashed black lines (b-g). 

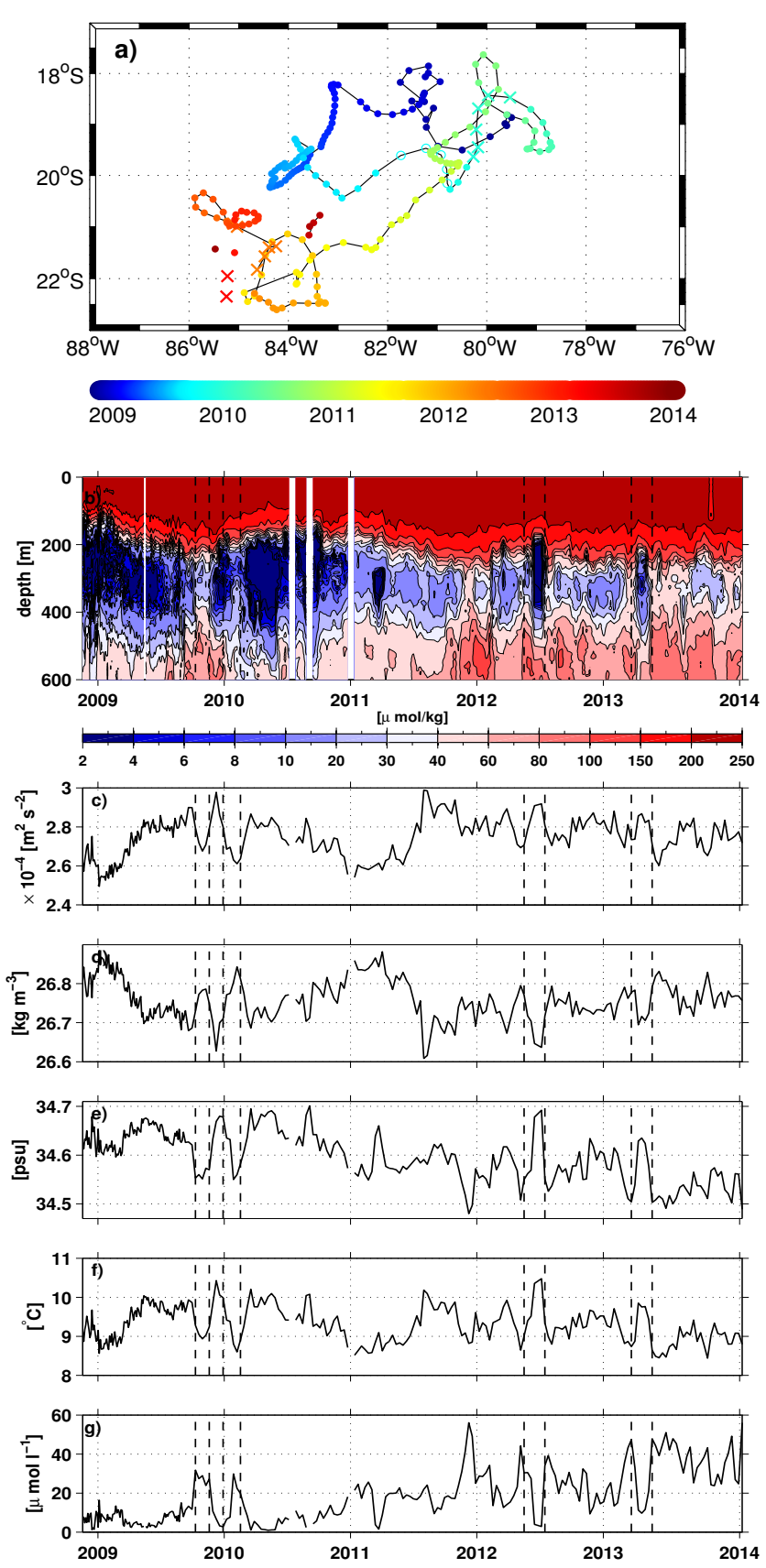

Figure 7. Measurements of float 3900729 in the tropical eastern South Pacific between 18 November 2008 and 6 February 2014 with (a) float path (color coded), (b) oxygen distribution versus time in the upper $600 \mathrm{~m}$, (c) geopotential anomaly ( 450 to $250 \mathrm{~m}$ ), (d) potential density anomaly in $350 \mathrm{~m}$ depth, (e) salinity in $350 \mathrm{~m}$, (f) potential temperature in $350 \mathrm{~m}$, and (g) oxygen in $350 \mathrm{~m}$. The residence time of the float in two cyclonic eddies (10 October to 19 November 2009, 29 December 2009 to 17 February 2010) and two anticyclonic mode water eddies (17 May to 16 July 2012, 23 March to 22 May 2013) is marked by Xs (a) and dashed black lines (b-g). In 2013 some profiles were recorded without the geographical location and only locations recorded are shown by dots or crosses not connected by a line.
Float 3900729 deployed on 18 November 2008 at $19.0^{\circ} \mathrm{S}$, $79.6^{\circ} \mathrm{W}$ had a lifetime of more than 5 years, and stayed during that time between 78 and $86^{\circ} \mathrm{W}$ (Fig. 7a). The oxygen time series shows several events where the oxygen below the mixed layer decreases and the low oxygen layer extends vertically. This is the signature of anticyclonic eddies. Anticyclonic eddies in the region off the coast of Peru show the main anomalies at deeper depths than cyclonic eddies (Chaigneau et al., 2011); thus, the anomalies for float 3900729 are presented at $350 \mathrm{~m}$ depth. In late 2009 and early 2010, two cyclonic eddies crossed the float path and these cyclonic eddies are seen because of their increasing oxygen layers (Fig. 7b), low 450-250 m geopotential anomaly and higher potential density anomaly, lower salinity, lower potential temperature and higher oxygen at $350 \mathrm{~m}$ depth (Fig. $7 \mathrm{c}-$ g). In mid-2012 and early 2013 two anticyclonic mode water eddies crossed the float path, visible as a vertically upward and downward extended low oxygen layer (Fig. 7b). These mode water eddies showed high $450-250 \mathrm{~m}$ geopotential anomaly and at $350 \mathrm{~m}$ depth lower potential density anomaly, higher salinity, higher potential temperature, and lower oxygen (Fig. $7 \mathrm{c}-\mathrm{g}$ ).

\subsection{Net community production estimates}

Floats with oxygen sensors active for several years cover several annual cycles of the mixed layer and the near-surface layer. From a float near Hawaii and from a float in the central South Pacific it was found that mixing events during early winter homogenize the upper water column and cause low oxygen concentrations. Oxygen then increases below the mixed layer at a nearly constant rate. This continuous oxygen increase is consistent with an ecosystem that is a net producer of fixed carbon throughout the year, with episodic events not required to sustain positive oxygen production (Riser and Johnson, 2008).

Primary production in the subtropical gyres is episodic and thus difficult to observe. Net community production (NCP), is equal to primary production minus respiration at all trophic levels. Oxygen that increases below the mixed layer at a nearly constant rate is similar to independent measures of NCP (Riser and Johnson, 2008), and oxygen sensors on profiling floats can be used to examine the balance of oxygen production and consumption. The oxygen measurements on floats led to highest NCP of about $15 \mathrm{mmol} \mathrm{C} \mathrm{m}^{-3} \mathrm{yr}^{-1}$ near Hawaii and about $7 \mathrm{mmol} \mathrm{C} \mathrm{m}^{-3} \mathrm{yr}^{-1}$ in the South Pacific gyre (Riser and Johnson, 2008). With a profiling float available in the eastern South Pacific about 20 to $30^{\circ}$ east of the float used by Riser and Johnson (2008), it is useful to check how NCP differs in the South Pacific zonally.

Here we apply the method as described by Riser and Johnson (2008) to derive the NCP from a float track located in the eastern South Pacific. The float 3900727 was deployed on 11 November 2008 at $19^{\circ} \mathrm{S}, 78.7^{\circ} \mathrm{W}$ (Fig. 8a) and moved northwestward for more than 5 years. The time series of potential 
density anomaly, salinity, potential temperature, and oxygen (Fig. 8b-e) clearly show the annual cycles. Periods of convective overturn in the upper $150 \mathrm{~m}$ during which potential density anomaly, salinity, potential temperature, and oxygen become vertically homogenous are present near the end of each year in response to the annual cycle of surface heat flux (Mechoso et al., 2014). Oxygen concentrations reach vertically uniform values during this period. In between, the convective overturn oxygen accumulates in the water trapped under the seasonal thermocline and produces a distinctive shallow oxygen maximum (Fig. 8e).

Generally, oxygen changes can be caused by changes in mixing, solubility, and biological production. Oxygen anomaly (oxygen saturation minus oxygen concentration, Fig. 9f) gives information about oxygen changes that are independent from solubility changes. The mean annual cycle over 5 years of oxygen concentration shows a continuous increase with time in the shallow oxygen maximum layer between about 40 and $80 \mathrm{~m}$ depth from mid-May to early April (Fig. 8e). Here we show the mean annual cycle of mixed layer depth, potential density anomaly, salinity, potential temperature, oxygen concentration, oxygen saturation, and oxygen anomaly (Fig. 9) in an example for the $64 \mathrm{~m}$ depth, which is the depth of the highest NCP only below the mixed layer depth (Fig. 10c).

Between mid-May and mid-November oxygen increase takes place above the seasonal thermocline and is primarily caused by solubility changes in the mixed layer (Fig. 9a, e), reflecting a decrease in salinity and potential temperature (Fig. 9c, d). Increase of oxygen concentration below the seasonal thermocline between mid-November and early April (Fig. 9a, e) cannot be driven by changes in oxygen saturation, which show, in fact, a decrease during that period (Fig. 9e) associated with an increase in salinity and potential temperature (Fig. 9c, d). As the float moves horizontally with the water parcels and the horizontal oxygen gradient is negligible, the oxygen increase must be caused by biological oxygen production.

The rate of oxygen production at a particular depth was determined after Riser and Johnson (2008) from the slope of a straight line that fits the oxygen data best in a least-square sense against time for the whole period of oxygen increase from mid-May to early April (about 320 days; Fig. 10a). The time interval is determined from the maximum slope of oxygen concentration against time for depth of 40 to $80 \mathrm{~m}$, where oxygen accumulates below the pycnocline (Fig. 8e). The increase of oxygen from the slope of the time series is then converted into carbon uptake with the modified Redfield ratio ( $150 \mathrm{~mol}$ of $\mathrm{O}_{2}$ produced per $106 \mathrm{~mol}$ of $\mathrm{CO}_{2}$ fixed; Anderson, 1995) for all depths. The daily increase is extrapolated to an annual rate of the NCP, which is the highest at the $58 \mathrm{~m}$ depth with a rate of $16.7 \pm 6 \mathrm{mmol} \mathrm{C} \mathrm{m}^{-3} \mathrm{yr}^{-1}$ (Fig. 10c). NCP estimates above $58 \mathrm{~m}$ depth are derived from the slope of oxygen anomaly (oxygen minus oxygen solubility) against time to determine the oxygen increase that is independent
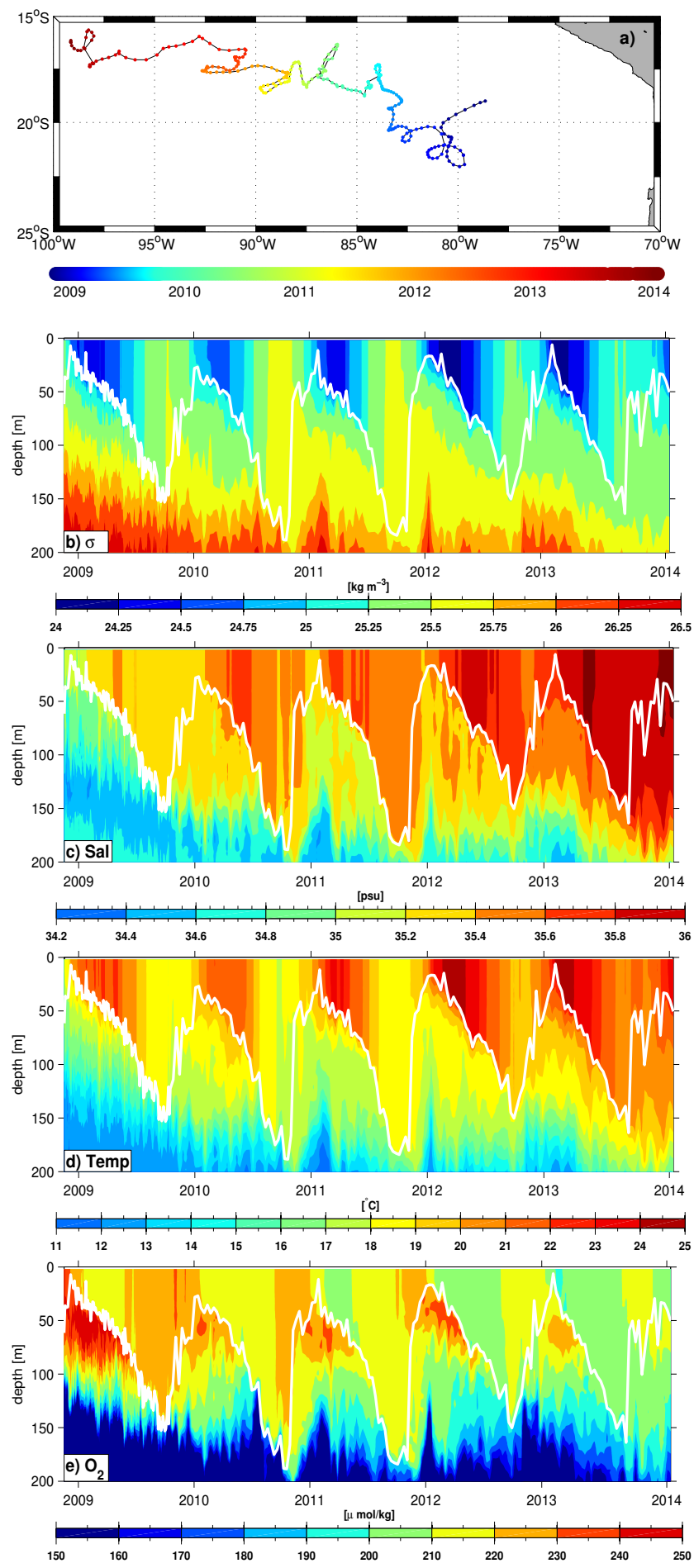

Figure 8. Measurements of float 3900727 in the tropical eastern South Pacific for the period 17 November 2008 to 11 February 2014 with (a) float path (color coded) and the distribution in the upper $200 \mathrm{~m}$ depth for (b) potential density anomaly, (c) salinity, (d) potential temperature, and (e) oxygen. The white curve in (b-e) is the mixed layer depth defined for the depth where the potential density anomaly is $0.125 \mathrm{~kg} \mathrm{~m}^{-3}$ larger than at the surface. 

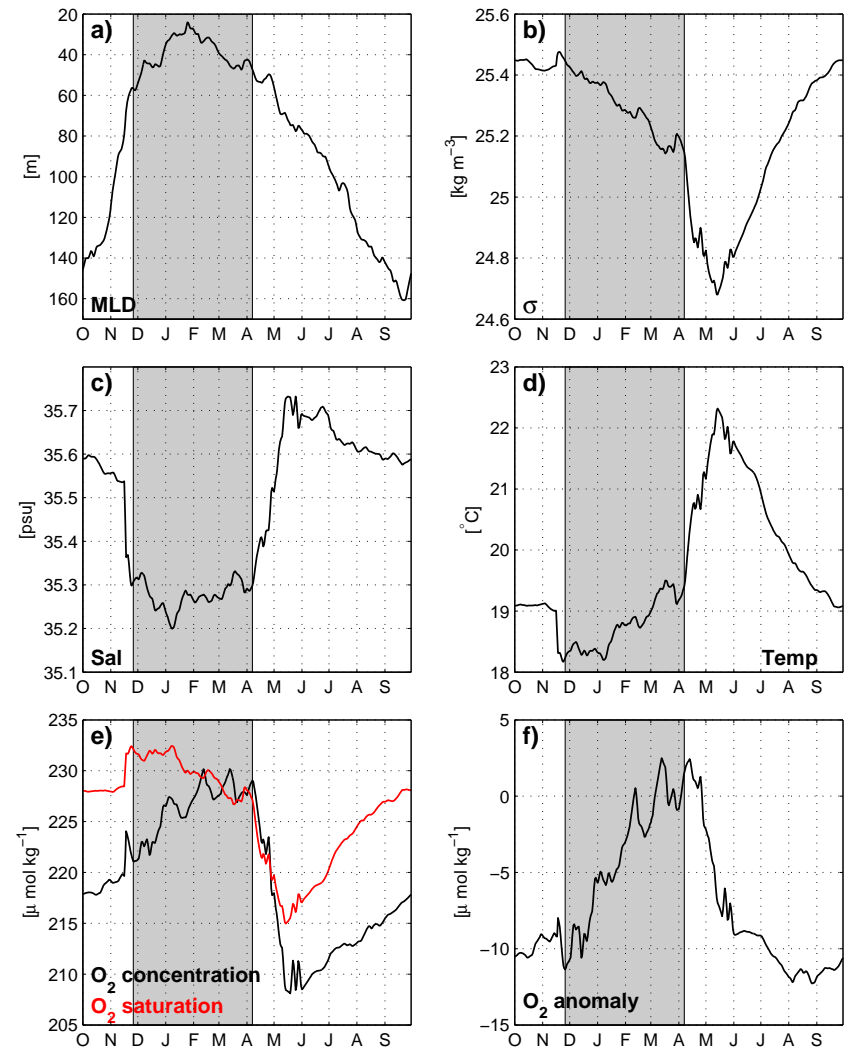

Figure 9. Mean annual cycle for the 5-year period 17 November 2008 to 16 November 2013 of float 3900727 in the tropical eastern South Pacific for (a) mixed layer depth (depth where the potential density anomaly is $0.125 \mathrm{~kg} \mathrm{~m}^{-3}$ larger than at the surface), and the distribution at $64 \mathrm{~m}$ depth for (b) potential density anomaly, (c) salinity, (d) potential temperature, (e) oxygen concentration (black curve) and oxygen saturation (red curve), and (f) oxygen anomaly (oxygen concentration minus oxygen solubility). Annual cycle plotted from October to end of September to follow the cycle of the mixed layer depth. The period of oxygen increase below the mixed layer between the end of November to early April is highlighted in grey.

from solubility changes in the mixed layer with the highest NCP value of $12.6 \pm 4.9 \mathrm{mmol} \mathrm{C} \mathrm{m}^{-3} \mathrm{yr}^{-1}$ in $48 \mathrm{~m}$ depth (Fig. 10c).

For comparison: NCP estimates from a float in the South Pacific gyre (Riser and Johnson, 2008) determined from the slope of the annual cycle of oxygen against time for the period from June to May show the highest value of $8.5 \pm 5 \mathrm{mmol} \mathrm{C} \mathrm{m}^{-3} \mathrm{yr}^{-1}$ at the $87 \mathrm{~m}$ depth (Fig. 10c) which is smaller than the value calculated from the data of the float propagating along the OMZ boundary. The NCP from the slope of oxygen anomaly against time within the mixed layer in the South Pacific also shows smaller rates with a maximum of $10 \pm 1.3$ in mmol $\mathrm{C} \mathrm{m}^{-3} \mathrm{yr}^{-1}$ in $87 \mathrm{~m}$ depth.

NCP rates determined from the slope of oxygen concentration against time in depth levels above the pycnocline can
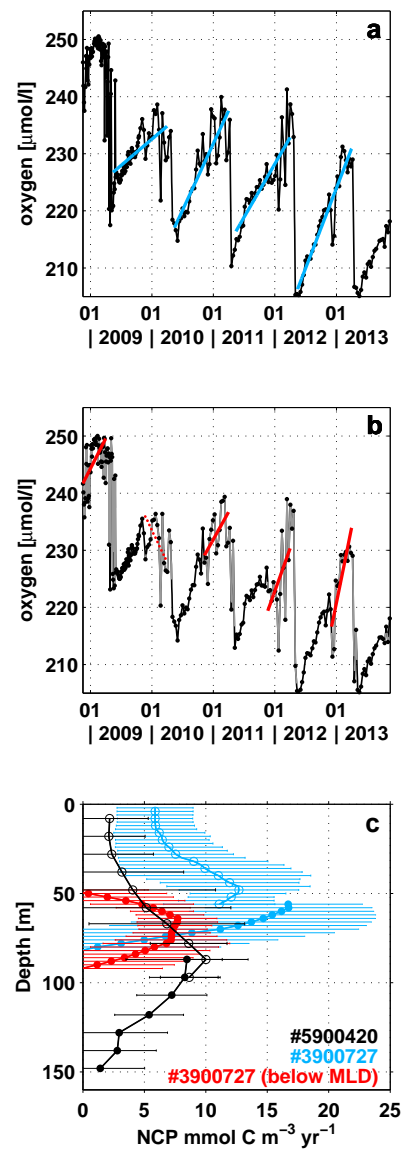

Figure 10. Oxygen concentration for float no. 3900727 at $58 \mathrm{~m}$ depth (a) and $64 \mathrm{~m}$ depth (b) shown as black lines and dots. Grey lines show the oxygen concentration below the mixed layer depth (b). Blue (a) and red (b) lines (dots) are fitted to the oxygen increase (decrease) each year for the period mid-May to early April (a) and for a period depending on the depth of the mixed layer (b). Net community production (NCP; in $\mathrm{mmol} \mathrm{C} \mathrm{m}^{-3} \mathrm{yr}^{-1}$; b) for float WMO no. 5900420 (at 20 to $22^{\circ} \mathrm{S}, 119$ to $128^{\circ} \mathrm{W}$; as used in Riser and Johnson, 2008) with oxygen slope against time computed for the period mid-June to early May (black circles and dots) and for float 3900727 (see Fig. 8) with oxygen slope against time for the period mid-May to early April (blue circles and dots) both extrapolated for 365 days. NCP calculated only below the mixed layer depth for float 3900727 with variable periods (red dots). Open symbols were calculated from the slope of oxygen anomaly (oxygenoxygen solubility) against time in the mixed layer. Solid symbols are an extrapolation to the surface of the highest rates based on the slope of oxygen against time at each site. Oxygen production was converted to carbon units using the modified Redfield ratio as in Riser and Johnson (2008). Error bars show the standard deviation of the NCP.

be imprecise due to oxygen loss to the atmosphere by gas exchange. Therefore, the rate of oxygen production is determined from the slope of oxygen concentration increase against time for every depth level strictly below the mixed layer to avoid oxygen changes due to solubility variations. 
The time intervals depend on the maximum slope of oxygen concentration and must be deeper than the mixed-layer depth (Fig. 10b). The NCP is highest in $64 \mathrm{~m}$ depth with a rate of $7.7 \pm 3.2 \mathrm{mmol} \mathrm{C} \mathrm{m}^{-3} \mathrm{yr}^{-1}$ (Fig. 10c) depending on a strong oxygen increase between the end of November to early April. However, oxygen concentration at $64 \mathrm{~m}$ decreases in the time interval from November 2009 to early April 2010. Due to oxygen loss below the mixed layer the NCP calculation for the period November 2009 to April 2010 was skipped (Fig. 10b).

\subsection{Changes on the $86^{\circ} \mathrm{W}$ repeat section}

The oxygen changes between March 1993 and November 2012 along the $86^{\circ} \mathrm{W}$ section (Fig. 11) show regions of increase as well as decrease between these two cruises. In the equatorial channel between $2^{\circ} \mathrm{N}$ and $5^{\circ} \mathrm{S}$, changes in oxygen similar to those seen between February 2009 and March 1993 on the same section (Czeschel et al., 2012; Fig. 7f) are present: a decrease of oxygen in the upper 350 to $400 \mathrm{~m}$ and an oxygen increase between 400 and $800 \mathrm{~m}$ depth are seen. In the core of the OMZ between 5 and $18^{\circ} \mathrm{S}$ there is mainly a weak oxygen increase between the March 1993 and the November 2012 cruise, with a region of oxygen decrease at 100 to $200 \mathrm{~m}$ depth and at mid-depth at 11 to $13^{\circ} \mathrm{S}$. The reversal between oxygen decrease and oxygen increase south of $18^{\circ} \mathrm{S}$ is in part related to the eddy activity in this region as can be seen in satellite sea-level height anomaly and the oxygen and density distribution in relation to the zonal velocity components (Fig. 2).

The oxygen changes in the region north of $18^{\circ} \mathrm{S}$ might be related to the El Niño state. For the eastern Pacific, the Niño $1+2$ index defined as the temperature anomaly for the area 0 to $10^{\circ} \mathrm{S}, 80-90^{\circ} \mathrm{W}$ is most relevant. The monthly Niño $1+2$ indices (http://www.cpc.ncep.noaa.gov/ data/indices/sstoi.indices) show for March $1993+0.65$, for April $1993+0.97$, for February $2009-0.11$, and for November $2012-0.38$. As the upper $400 \mathrm{~m}$ in the eastern equatorial Pacific experience an oxygen increase during El Niño periods (e.g., Czeschel et al., 2012) the lower oxygen in the upper ocean seem to be caused by the El Niño status. A comparison with an extended optimum multi-parameter analysis between the sections in March 1993 and February 2009 showed that during a cold phase the upward flow of relatively oxygen-rich Antarctic intermediate water (AAIW) into the depth range 150 to $500 \mathrm{~m}$ and the flow of AAIW at shallower depths leads to higher oxygen values in the upper OMZ (Llanillo et al., 2013). As the Niño $1+2$ index shows an even larger cold phase for November 2012 compared to February 2009, the oxygen increase north of $18^{\circ} \mathrm{S}$ below $400 \mathrm{~m}$ seems to be caused also by the El Niño phase differences. As a consequence, the comparison in oxygen changes between single ship sections has to be interpreted with great care taking El Niño phases and eddies as well as seasonal signals into account.

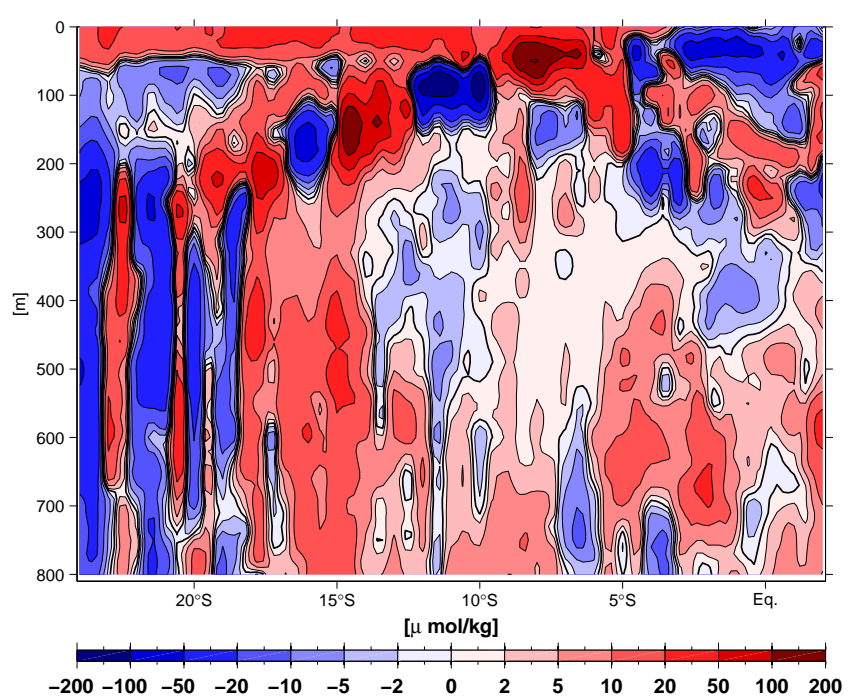

Figure 11. Oxygen differences along the section at about $86^{\circ} \mathrm{W}$ between November 2012 and March 1993.

The Interdecadal Pacific Oscillation (IPO; Power et al., 1999 ) is almost the Pacific-wide manifestation of the Pacific decadal oscillation with strong variability in the Southern Hemisphere as well as in the Northern Hemisphere. Pronounced strengthening in Pacific trade winds over the past 2 decades has accounted for cooling of the tropical Pacific and slowing down the surface warming. At the same time, the accelerated trade winds have increased equatorial upwelling on the central and eastern Pacific, lowering sea surface temperature there (England et al., 2014). In the schematic figure for the trends in temperature and circulation between a positive IPO and a negative IPO between 1992 to 2011 (England et al., 2014; their Fig. 3), a negative temperature deviation and stronger westward flow anomalies are present in the upper 200 to $300 \mathrm{~m}$ in the eastern equatorial Pacific. The potential temperature differences along $85^{\circ} 50^{\prime} \mathrm{W}$ between February 2009 and March 1993 show the proposed decrease in potential temperature in the upper $300 \mathrm{~m}$ near the Equator (Fig. 12a) as well as a decrease in oxygen and a stronger relative westward flow component (Fig. 12b). Measurements in late March 2009 resulted in a EUC flow of 7-11 Sv (Collins et al., 2013), less than the 16.3 Sv for late March 1993. The fact that the velocity difference between February 2009 and March 1993 (Fig. 12b) is restricted not only to the EUC but also to the region north of $5^{\circ} \mathrm{S}$ points to a larger-scale decrease in the velocity field. Hence, the difference in potential temperature and the velocity component between 1993 and 2009 is in agreement to the proposed intensification of winddriven circulation in the Pacific (England et al., 2014).

\subsection{Nutrient changes}

Redfield et al. (1963) were the first to notice that the ratio of elements in seawater is remarkably similar to that of liv- 
ing and dead biomass, namely, the ratios $\left(\mathrm{P}: \mathrm{N}: \mathrm{C}: \mathrm{O}_{2}\right)$ are $1: 16: 106: 138$. Oxidation of biological debris leads to an increase of phosphate $\left(\mathrm{PO}_{4}\right)$, nitrate $\left(\mathrm{NO}_{3}\right)$, and carbon dioxide $\left(\mathrm{CO}_{2}\right)$ while oxygen is consumed. In the subarctic Pacific Ocean, nutrient enrichment in nitrate, phosphate, and silicate has been observed since the mid-1980s while oxygen decreased (Whitney et al., 2013). Similar trends were described for the California current (Bograd et al., 2015) and the question arises whether such nutrient trends exist also in the eastern tropical Pacific. Nutrient measurements in the open tropical and South Pacific Ocean are sparse. Oxygen trends at about $86^{\circ} \mathrm{W}$ have been computed since 1976 for the upper $700 \mathrm{~m}$ from existing historical data and the Meteor cruise in February 2009 (Czeschel et al., 2012). For the region along the November 2012 cruise track we checked the availability of nutrient data in the historical database. In the regions $2^{\circ} \mathrm{N}$ to $2^{\circ} \mathrm{S}, 2$ to $5^{\circ}$, and 5 to $8^{\circ} \mathrm{S}$ it was possible to compute the oxygen and nutrient trends. South of $8^{\circ} \mathrm{S}$ historical data are too sparse along the cruise track to compute nutrient trends. As historical nutrient measurements are focused on the upper ocean and as the nutrient changes will have the largest impact on the biology in the upper ocean, the trends since 1976 have been computed for three equatorial areas for the layer 50 to $300 \mathrm{~m}$ (Table 2). The area $2^{\circ} \mathrm{N}$ to $2^{\circ} \mathrm{S}$ represents the region of the eastward flowing EUC, 2 to $5^{\circ} \mathrm{S}$ the westward flowing SEC/SEIC region, and 5 to $8^{\circ} \mathrm{S}$ the eastward flowing SSCC region.

The oxygen trend for all three areas is negative and significant with slightly more than $1 \mu \mathrm{mol} \mathrm{kg} \mathrm{gr}^{-1}$. Floats with oxygen sensors deployed in the investigation area confirm the oxygen trend derived from the Meteor stations sampled in February 2009 (Fig. 13a). Although only a few years were available for the nutrient trend computations, the positive trends for nitrate and phosphate are seen in all three areas and are significant within $95 \%$ at $2^{\circ} \mathrm{N}-2^{\circ} \mathrm{S}$ and $2-5^{\circ} \mathrm{S}$ for nitrate and $2-5^{\circ} \mathrm{S}$ for phosphate (Fig. 13). Silicate trends are not significant and change from a positive trend between $2^{\circ} \mathrm{N}$ and $5^{\circ} \mathrm{S}$ to a negative trend at 5 to $8^{\circ} \mathrm{S}$. Measurement errors are small compared to the observed trends. For recent autoanalyzer measurements, precisions are $0.01 \mu \mathrm{mol} \mathrm{kg}^{-1}$ for phosphate, $0.1 \mu \mathrm{mol} \mathrm{kg}{ }^{-1}$ for nitrate, $0.5 \mu \mathrm{mol} \mathrm{kg}{ }^{-1}$ for silicate, and $0.02 \mathrm{~mL} \mathrm{~L}^{-1}\left(\sim 0.09 \mu \mathrm{mol} \mathrm{kg}{ }^{-1}\right)$ for oxygen from Winkler titration (Bograd et al., 2015). For older uncorrected nutrient data, offsets are estimated at $3.5 \%$ for nitrate, $6.2 \%$ for silicate, and $5.1 \%$ for phosphate (Tanhua et al., 2010). Whitney et al. (2013) hypothesized that warming and oxygen loss in the subarctic Pacific pycnocline initiated a vertical redistribution of nutrients due to compression of vertical migrator habitat with changes in productivity and/or changes in dissolution of sinking particles are responsible for the nutrient changes. Such processes could be also at work in the region of decreasing oxygen in the equatorial channel of the Pacific Ocean.

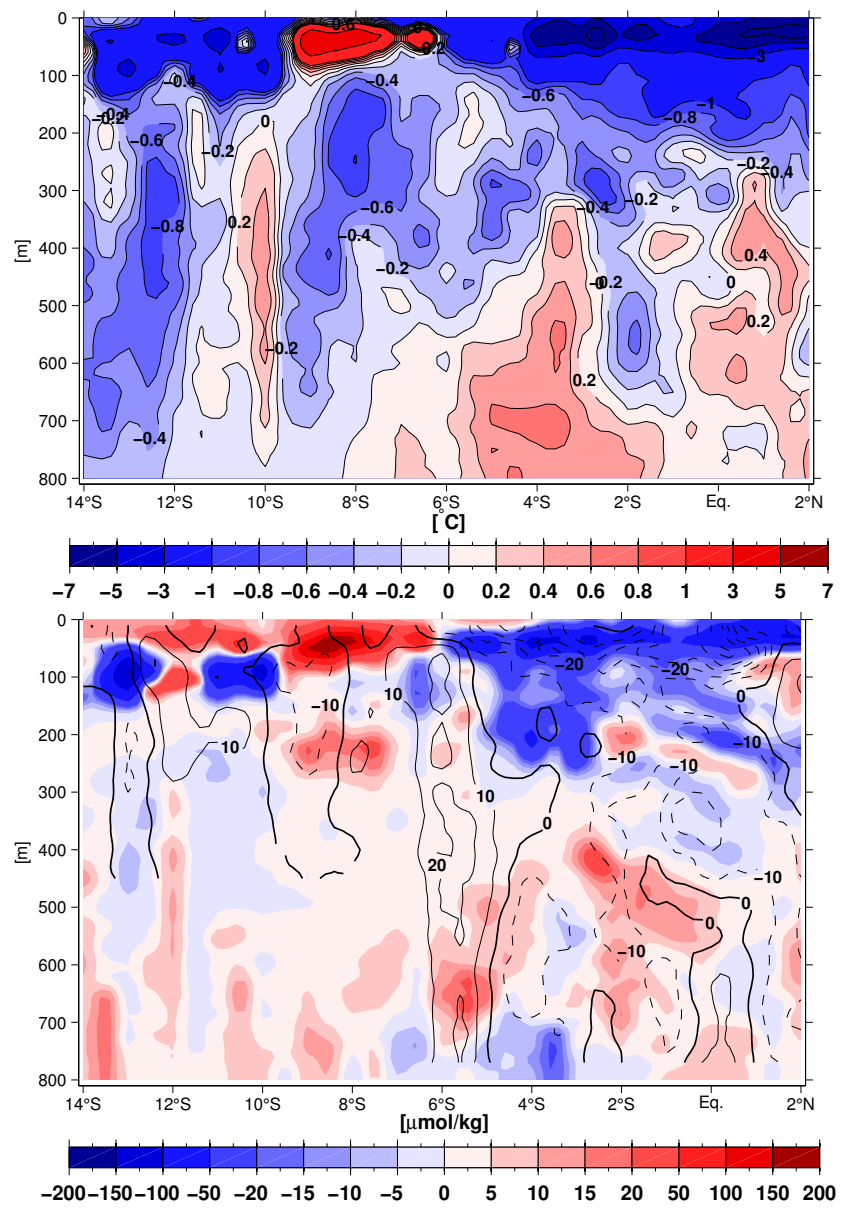

Figure 12. Distribution of differences along $85^{\circ} 50^{\prime} \mathrm{W}$ between February 2009 and March 1993 in (top) potential temperature in ${ }^{\circ} \mathrm{C}$ and (bottom) oxygen in $\mu \mathrm{mol} \mathrm{kg}{ }^{-1}$ (color) and ADCP measured zonal velocity (black contours; $\mathrm{cm} \mathrm{s}^{-1}$; positive eastward).

\section{Summary and concluding remarks}

In this study the ETSP off the coast of Peru was investigated from recent ship cruises, profiling floats, and historical hydrographic data. The oxygen and velocity distribution in November/December 2012 in different depth layers between 50 and $600 \mathrm{~m}$ depth indicated that the expected mean circulation of the tropical eastern South Pacific is modified by seasonal variability such as that of the EUC, which is known to show a seasonal signal, and by eddies on the poleward side of the OMZ. In November 2012 the equatorial undercurrent (EUC) east of the Galapagos islands was centered at $250 \mathrm{~m}$ depth, deeper than in earlier observations (e.g., Karnauskas et al., 2010; Czeschel et al., 2011). The EUC merged with the SICC and no EIC is present in November 2012. The shallow part of the EUC was absent or shifted southward to $3-4^{\circ} \mathrm{S}$ in the upper $100 \mathrm{~m}$ depth carrying relatively oxygen-rich water eastward at $50 \mathrm{~m}$ depth (Fig. 3a). 
Table 2. Linear trends of solutes in $\mu \mathrm{mol} \mathrm{kg} \mathrm{kg}^{-1} \mathrm{yr}^{-1}$ with $95 \%$ confidence intervals since 1976 in a 50 to $300 \mathrm{~m}$ layer for the ocean areas between 84 and $87^{\circ} \mathrm{W}$ for $2^{\circ} \mathrm{N}-2^{\circ} \mathrm{S}$ (Fig. 13), 2-5 ${ }^{\circ}$, and $5-8^{\circ} \mathrm{S}$. For phosphate at $2^{\circ} \mathrm{N}-2^{\circ} \mathrm{S}$ the years 1978 and 1979 and for silicate at $2-5^{\circ} \mathrm{S}$ the year 1976 were removed due to unrealistic low annual mean values. Trends not within the $95 \%$ confidence interval are shown in brackets.

\begin{tabular}{llll}
\hline Parameter & $2^{\circ} \mathrm{N}-2^{\circ} \mathrm{S}$ & $2-5^{\circ} \mathrm{S}$ & $5-8^{\circ} \mathrm{S}$ \\
\hline Oxygen & $-1.02 \pm 0.49$ & $-1.23 \pm 0.67$ & $-1.02 \pm 0.84$ \\
Nitrate & $+0.139 \pm 0.112$ & $+0.245 \pm 0.165$ & $(+0.101 \pm 0.179)$ \\
Phosphate & $(+0.0050 \pm 0.0095)$ & $+0.0110 \pm 0.0087$ & $(+0.0051 \pm 0.0079)$ \\
Silicate & $(+0.0461 \pm 0.1880)$ & $(+0.0127 \pm 0.0734)$ & $(-0.0483 \pm 0.0699)$ \\
\hline
\end{tabular}
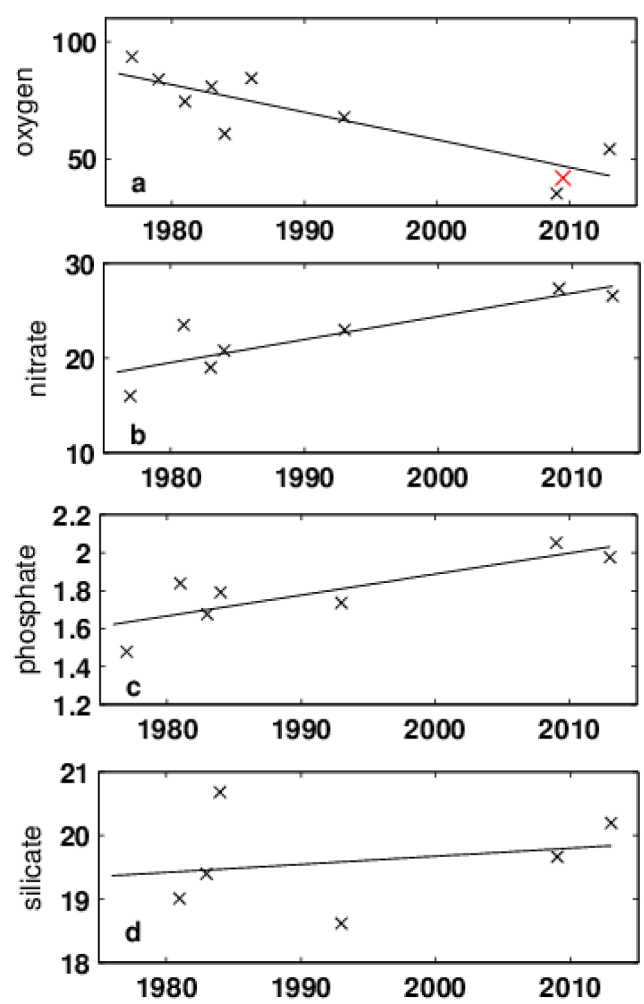

Figure 13. Trends since 1976 for the layer 50 to $300 \mathrm{~m}$ depth between 2 and $5^{\circ} \mathrm{S}$ and 84 and $87^{\circ} \mathrm{W}$ in $\mu \mathrm{mol} \mathrm{kg} \mathrm{gr}^{-1}$ for (a) oxygen, (b) nitrate, (c) phosphate, and (d) silicate. For silicate the year 1976 was removed due to an unrealistic mean value $\left(14.9 \mu \mathrm{mol} \mathrm{kg} \mathrm{yr}^{-1}\right)$. The red cross in (a) is the mean oxygen value for 2009 from profiling floats with oxygen sensors which provided profiles in the investigation area.

The southeastward continuation of the equatorial water near the Peruvian shelf in the depth range of 25 to $500 \mathrm{~m}$ within the PCUC in December 2012 showed a mean transport of $1.4 \mathrm{~Sv}$ for eight sections between 5 and $16^{\circ} \mathrm{S}$ and is in agreement with long-term ADCP measurements of the PCUC of $1.6 \pm 0.4 \mathrm{~Sv}$ (Chaigneau et al., 2013). Chaigneau et al. (2013) state that the PCUC experiences relatively weak seasonal variability; hence, the December 2012 transports agree very well with the mean PCUC transport. An anticy- clonic eddy located south of the $16^{\circ} \mathrm{S}$ section reduced the PCUC transport considerably. The oxygen distribution on the eight sections shows little enhanced oxygen at 5 and $7^{\circ} \mathrm{S}$ in the PCUC from oxygenated water from the equatorial channel, while south of $7^{\circ} \mathrm{S}$ the PCUC turns oxygen poor. Float measurements turned out to be a useful tool for long-term surveys of the ocean, especially floats with oxygen sensors. The floats deployed with a parking depth at $400 \mathrm{~m}$ show fast westward flow in the equatorial channel, while none of the equatorial floats moved towards the South American continent. The floats deployed at $8^{\circ} \mathrm{S}$ and south of $8^{\circ} \mathrm{S}$ indicate a sluggish southwestward flow in the northern part of the $\mathrm{OMZ}$ and sluggish variable northwestward and southwestward shift near $20^{\circ} \mathrm{S}$. A float which stayed in a cyclonic eddy for more than half a year monitored the related parameter changes in the eddy. The SSHA during that time was in good agreement with the subsurface geopotential anomaly (Fig. 6) and it shows that cyclonic eddies are well visible in SSHA maps. From a float with an oxygen sensor and a lifetime of more than 5 years drifting from about $20^{\circ} \mathrm{S}, 80^{\circ} \mathrm{W}$ to $16^{\circ} \mathrm{S}, 98^{\circ} \mathrm{W}$ it was possible to estimate the NCP with the highest NCP rate in $58 \mathrm{~m}$ depth extrapolated to an annual rate of $16.7 \mathrm{mmol} \mathrm{C} \mathrm{m}^{-3} \mathrm{yr}^{-1}$. This computation is similar to the approach by Riser and Johnson (2008), who derived a maximum of $8 \mathrm{mmol} \mathrm{C} \mathrm{m}^{-3} \mathrm{yr}^{-1}$ for a float in the South Pacific in the area of $20-24^{\circ} \mathrm{S}, 118-128^{\circ} \mathrm{W}$. However, when only the time period is used when the float stayed below the mixed layer, the highest NCP was found at $64 \mathrm{~m}$ depth with $7.7 \mathrm{mmol} \mathrm{C} \mathrm{m}^{-3} \mathrm{yr}^{-1}$. The higher annual rate in our easternmost float is related to the higher productivity in the eastern South Pacific, while the float in the central South Pacific operated in a region that is considered to have one of the lowest rates of primary production in the world ocean (Behrenfeld et al., 2005; Riser and Johnson, 2008). The lower primary production further west is visible in the reduced oxygen increase in the water trapped under the seasonal thermocline from year to year while the float moved westward (Fig. 8a, e).

Changes on repeat sections have to be considered with care, as the differences are influenced by the El Niño phase and seasonal changes. The observed difference in potential temperature and the velocity component in the tropical $\mathrm{Pa}$ - 
cific at $86^{\circ} \mathrm{W}$ between 1993 and 2009 is in agreement with the proposed intensification of wind-driven circulation in the Pacific, probably related to the IPO as suggested by England et al. (2014). Investigations of the different timescales and space scales are necessary to better understand the parameter distribution and circulation and its changes in the ETSP.

In the open tropical eastern South Pacific, historical data sets for oxygen and nutrients are sparse; however, it was possible to compute oxygen and nutrient trends in three regions at about $86^{\circ} \mathrm{W}$ between $2^{\circ} \mathrm{N}$ and $8^{\circ} \mathrm{S}$. These trends in the layer 50 to $300 \mathrm{~m}$ depth since 1976 show a decreasing oxygen trend related to increasing nitrate and phosphate trends. Similar oxygen and nutrient trends were reported for the subarctic Pacific Ocean (Whitney et al., 2013) and the California current region (Bograd et al., 2015); however, more detailed biological and chemical investigations are needed to understand the trends and changes in oxygen and in nutrients.

\section{The Supplement related to this article is available online at doi:10.5194/os-11-455-2015-supplement.}

Acknowledgements. The Deutsche Forschungsgemeinschaft (DFG) provided support as part of the "Sonderforschungsbereich 754: Climate-Biogeochemistry Interactions in the Tropical Ocean, A5" (RC, LS). Additional support was provided through the German BMBF funded Project SOPRAN under FKZ 03F0662A (TF) and through the US NOAA Climate Program Office to the Woods Hole Oceanographic Institution (RAW). We thank G. Krahmann, M. Lohmann, and T. Baustian for providing measurements and final processing of the various data sets presented. We thank participants in VOCALS for help in deploying profiling floats. The altimeter data were produced by Ssalto/Duacs and distributed by Aviso with support from Cnes. The Argo float profiles are available from ftp://ftp.ifremer.fr/ifremer/argo/dac/coriolis. We thank the authorities of Peru for the permission to work in their territorial waters.

\section{Edited by: C. Garbe}

\section{References}

Anderson, L. A.: On the hydrogen and oxygen content of marine phytoplankton, Deep-Sea Res. I, 42, 1675-1680, 1995.

Ayon, P., Criales-Hernandez, M. I., Schwamborn, R., and Hirche, H.-J.: Zooplankton research off Peru: A review, Prog. Oceanogr., 79, 238-255, 2008.

Behrenfeld, M. J., Boss, E., Siegel, D. A., and Shea, D. M.: Carbon-based ocean productivity and phytoplankton physiology from space, Global Biogeochem. Cy., 19, doi:10.1029/2004GB002299, 2005.

Bograd, S. J., Pozo Buil, M., Di Lorenzo, E., Castro, C. G., Schroeder, I. D., Goericke, R., Anderson, C. R., BenitezNelson, C., and Whitney, F. A.: Changes in source waters to the Southern California Bight, Deep-Sea Res. II, 112, 42-52, doi:10.1016/j.dsr2.2014.04.009, 2015.

Chaigneau, A., Gizolme, A., and Grados, C.: Mesoscale eddies off Peru in altimeter records: Identification algorithms and eddy spatio-temporal patterns, Prog. Oceanogr., 79, 106-119, 2008.

Chaigneau, A., Le Texier, M., Eldin, G., Grados, C., and Pizarro, O.: Vertical structure of mesoscale eddies in the eastern South Pacific Ocean: A composite analysis from altimetry and Argo profiling floats, J. Geophys. Res., 116, C11025, doi:10.1029/2011JC007134, 2011.

Chaigneau, A., Dominguez, N., Eldin, G., Vasquez, I., Flores, R., Grados, C., and Echevin, V.: Near-coastal circulation in the northern Humboldt Current system from shipboard ADCP data, J. Geophys. Res., 118, 5251-5266, doi:10.1002/jgrc.20328, 2013.

Chavez, F. P., Bertrand, A., Guevara-Carrasco, R., Soler, P., and Csirke, J.; The northern Humboldt Current System: Brief history, present status and a view towards the future, Prog. Oceanogr., 79. 95-105, doi:10.1016/j.pocean.2008.10.012, 2008.

Chelton, D. B., Schlax, M. G., and Samelson, R. M.: Global observations of nonlinear mesoscale eddies, Prog. Oceanogr., 91, 167-216, doi:10.1016/j.pocen.2011.01.002, 2011.

Collins, C., Mascarenhas, A., and Martinez, R.: Structure of ocean circulation between the Galapagos Islands and Ecuador, Adv. Geosci. 33, 3-12, doi:10.5194/adgeo-33-3-2013, 2013.

Cravatte, S., Madec, G., Izumo, T., Menkes, C., and Bozec, A.: Progress in the 3-D circulation of the eastern equatorial Pacific in a climate model, Ocean Model., 17, 28-48, doi:10.1016/j.oceamod.2006.11.003, 2007.

Cravatte, S., Kessler, W. S., and Marin, F.: Intermediate zonal jets in the tropical Pacific Ocean observed by Argo floats, J. Phys. Oceanogr., 42, 1475-1485, doi:10.1175/JPO-D-11-0206.1, 2012.

Czeschel, R., Stramma, L., Schwarzkopf, F. U., Giese, B. J., Funk, A., and Karstensen, J.: Middepth circulation of the eastern tropical South Pacific and its link to the oxygen minimum zone, J. Geophys. Res., 116, C01015, doi:10.1029/2010JC006565, 2011.

Czeschel, R., Stramma, L., and Johnson, G. C.: Oxygen decreases and variability in the eastern equatorial Pacific, J. Geophys. Res., 117, C01019, doi:10.1029/2012JC008043, 2012.

Deutsch, C., Brix, H., Ito, T., Frenzel, H., and Thompson, L.: Climate-forced variability of ocean hypoxia, Science, 333, 336339, doi:10.1126/science.1202422, 2011.

England, M. H., McGregor, S., Spence, P., Meehl, G. A., Timmermann, A., Cai, W., Sen Gupta, A., McPhaden, M. J., Purich, A., and Santoso, A.: Recent intensification of wind-driven circulation in the Pacific and the ongoing warming hiatus, Nature Clim. Change, 4, 222-227, doi:10.1038/NCLIMATE2106, 2014.

Firing, E., Wijffels, S. E., and Hacker, P., Equatorial subthermocline currents across the Pacific, J. Geophys. Res., 103, 21413-21423, doi:10.1029/98JC01944, 1998.

Grasse, P., Stichel, T., Stumpf, R., Stramma, L., and Frank, M.: The distribution of neodymium isotopes and concentrations in the eastern equatorial Pacific: Water mass advection versus particle exchange, Earth Planet. Sci. Lett., 353-354, 198-207, 2012.

Hansen, H. P.: Determination of oxygen, in: Methods of Seawater analysis, edited by: Grasshoff, K. K. and Ehrhardt, M., WileyVCH, Weinheim, 75-89, 1999. 
Hormazabal, S., Combes, V., Morales, C. E., Correa-Ramirez, M., Di Lorenzo, E., and Nunez, S.: Intrathermocline eddies in the coastal transition zone off central Chile $\left(31-41^{\circ} \mathrm{S}\right)$, J. Geophys. Res., 118, 1-11, doi:10.1002/jgrc.20337, 2013.

Karnauskas, K. B., Murtugudde, R., and Busalacchi, J.: Observing the Galapagos-EUC interaction: Insights and challenges, J. Phys. Oceanogr., 40, 2768-2777, doi:10.1175/2010JPO4461.1, 2010.

Kessler, W. S.: The circulation of the eastern tropical Pacific: a review, Prog. Oceanogr., 89, 181-217, doi:10.1016/j.pocean.2006.03.009, 2006.

Keeling, R. F., Körtzinger, A., and Gruber, N.: Ocean deoxygenation in a warming world, Annu. Rev. Mar. Sci., 2, 199-229, doi:10.1146/annurev.marine.010908.163855, 2010.

Klein, P. and Lapeyre, G.: The oceanic vertical pump induced by mesoscale and submesoscale turbulence, Annu. Rev. Mar. Sci., 1, 351-373, 2009.

Llanillo, P. J., Karstensen, J., Pelegri, J. L., and Stramma, L.: Physical and biogeochemical forcing of oxygen and nitrate changes during El Nino/El Viejo and La Nina/La/Vieja upper-ocean phases in the tropical eastern South Pacific along $86^{\circ} \mathrm{W}$, Biogeosciences, 10, 6339-6355, doi:10.5194/bg-10-6339-2013, 2013.

Lukas, R.: The termination of the Equatorial Undercurrent in the Eastern Pacific, Prog. Oceanogr., 16, 63-90, 1986.

McGillicuddy Jr., D. J.: Formation of Intraseasonal lenses by eddy-wind interaction, J. Phys. Oceanogr., 45, 606-612, doi:10.1175/JPO-D-14-0221.1, 2015.

McGillicuddy Jr., D. J., Anderson, L. A., Bates, N. R., Bibby, T., Buesseler, K. O., Carlson, C. A., Davis, C. S., Ewart, C., Falkowski, P. G., Goldthwait, S. A., Hansell, D. A., Jenkins, W. J., Johnson, R., Kosnyrev, V. K., Ledwell, J. R., Li, Q. P., Siegel, D. A., and Steinberg, D. K.: Eddy/wind interactions stimulate extraordinary mid-ocean plankton blooms, Science, 316, 10211026, 2007

Mechoso, C. R., Wood, R., Weller, R., Bretherton, C. S., Clarke, A. D., Coe, H., Fairall, C., Farrar, J. T., Feingold, G., Garreaud, R., Grados, C., McWilliams, J., de Szoeke, S. P., Yuter, S. E., and Zuidema, P.: Ocean-Cloud-Atmosphere-Land Interactions in the Southeastern Pacific: The VOCALS Program, B. Am. Meteor. Soc., 95, 357-375, doi:10.1175/BAMS-D-11-00246.1, 2014.

Pietri, A., Echevin, V., Testor, P., Chaigneau, A., Mortier, L., Grados, C., and Albert, A.: Impact of a coastal-trapped wave on the near-coastal circulation of the Peru upwelling system from glider data, J. Geophys. Res. Oceans, 119, 2109-2120, doi:10.1002/2013JC009270, 2014.

Power, S., Casey, T., Folland, C. K., Colman, A., and Mehta, V.: Inter-decadal modulation of the impact of ENSO on Australia, Clim. Dynam., 15, 319-323, 1999.

Redfield, A. C., Ketchum, B. H., and Richards, F. A.: The influence of organisms on the composition of sea water, in: The Sea, vol. 2, edited by: Hill, M. N., Interscience, New York, 26-27, 1963.
Ridgway, K. R., Dunn, J. R., and Wilkin, J. L.: Ocean interpolation by four-dimensional least squares-Application to the waters around Australia, J. Atmos. Ocean. Technol., 19, 1357-1375, 2002.

Riser, S. C. and Johnson, K. S.: Net production of oxygen in the subtropical ocean, Nature, 451, 323-325, doi:10.1038/nature06441, 2008.

Rowe, D. G., Firing, E., and Johnson, G. C.: Pacific equatorial subsurface countercurrent velocity, transport and potential vorticity, J. Phys. Oceanogr., 30, 1172-1187, 2000.

Stramma, L., Schmidtko, S., Levin, L. A., and Johnson, G. C.: Ocean oxygen minima and their biological impacts, Deep-Sea Res., I, 57, 587-595, doi:10.1016/j.dsr.2010.01.005, 2010a.

Stramma, L., Johnson, G. C., Firing, E., and Schmidtko, S.: Eastern Pacific oxygen minimum zones: Supply paths and multidecadal changes, J. Geophys. Res., 115, C09011, doi:10.1029/2009JC005976, 2010b.

Stramma, L., Bange, H. W., Czeschel, R., Lorenzo, A., and Frank, M.: On the role of mesoscale eddies for the biological productivity and biogeochemistry in the eastern tropical Pacific off Peru, Biogeosciences, 10, 7293-7306, doi:10.5194/bg-10-7293-2013, 2013.

Stramma, L., Weller, R. A., Czeschel, R., and Bigorre, S.: Eddies and an extreme water mass anomaly observed in the eastern South Pacific at the Stratus mooring, J. Geophys. Res. Oceans, 119, 1068-1083, doi:10.1002/2013JC009470, 2014.

Tanhua, T., van Heuven, S., Key, R. M., Velo, A., Olsen, A., and Schirnick, C.: Quality control procedures and methods of the CARINA database, Earth Syst. Sci. Data, 2, 35-49, doi:10.5194/essd-2-35-2010, 2010.

Tatebe, H., Imada, Y., Mori, M., Kimoto, M., and Hasumi, H.: Control of decadal and bidecadal climate variability in the tropical Pacific by the off-equatorial South Pacific Ocean, J. Climate, 26, 6524-6534, doi:10.1175/JCLI-D-12-00137.1, 2013.

Tsuchiya, M. and Talley, L. D.: A Pacific hydrographic section at $88^{\circ} \mathrm{W}$ : water-property distribution, J. Geophys. Res., 103, 12899-12918, 1998.

Ulloa, O., Canfield, D. E., DeLong, E. F., Letelier, R. M., and Stewart, F. J.: Microbial oceanography of anoxic oxygen minimum zones, P. Natl. Acad. Sci., 109, 15996-16003, doi:10.1073/pnas.1205009109, 2012.

Whitney, F. A., Bograd, S. J., and Ono, T.: Nutrient enrichment of the subarctic Pacific Ocean pycnocline, Geophys. Res. Lett., 40, 2200-2205, doi:10.1002/grl.50439, 2013.

Winkler, L. W.: Bestimmung des im Wasser gelösten Sauerstoffs, Ber. Dtsch. Chem. Ges., 21, 2843-2855, 1888. 